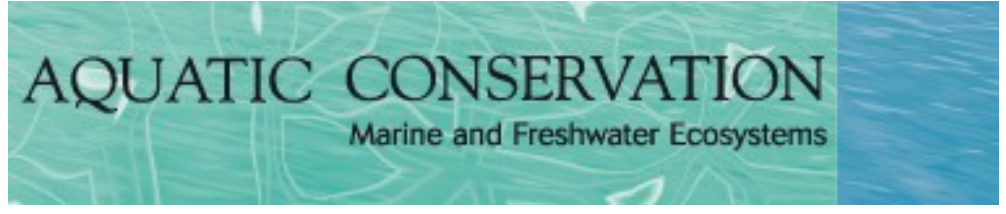

\title{
Changing distribution of the east coast of Scotland bottlenose dolphin population and the challenges of area- based management
}

\begin{tabular}{|c|c|}
\hline Journal: & Aquatic Conservation: Marine and Freshwater Ecosystems \\
\hline Manuscript ID & AQC-18-0287.R2 \\
\hline Wiley - Manuscript type: & Supplement Article \\
\hline $\begin{array}{l}\text { Date Submitted by the } \\
\text { Author: }\end{array}$ & $\mathrm{n} / \mathrm{a}$ \\
\hline Complete List of Authors: & $\begin{array}{l}\text { Arso Civil, Mònica; University of St Andrews, Sea Mammal Research Unit, } \\
\text { Scottish Oceans Institute } \\
\text { Quick, Nicola; Duke University Marine Laboratory, } \\
\text { Cheney, Barbara; University of Aberdeen, Lighthouse Field Station } \\
\text { Pirotta, Enrico; Washington State University - Vancouver, School of } \\
\text { Mathematics; University of Aberdeen, Lighthouse Field Station; } \\
\text { University College Cork National University of Ireland, School of } \\
\text { Biological, Earth and Environmental Sciences } \\
\text { Thompson, Paul; University of Aberdeen, Lighthouse Field Station } \\
\text { Hammond, Philip; University of St Andrews, Sea Mammal Research Unit }\end{array}$ \\
\hline $\begin{array}{l}\text { Broad habitat type } \\
\text { (mandatory) select 1-2: }\end{array}$ & coastal $<$ Broad habitat type, estuary $<$ Broad habitat type \\
\hline $\begin{array}{l}\text { General theme or application } \\
\text { (mandatory) select } 1-2 \text { : }\end{array}$ & $\begin{array}{l}\text { Special Area of Conservation < General theme or application, } \\
\text { conservation evaluation }<\text { General theme or application }\end{array}$ \\
\hline $\begin{array}{l}\text { Broad taxonomic group or } \\
\text { category (mandatory, if } \\
\text { relevant to paper) select } 1-2 \text { : }\end{array}$ & mammals $<$ Broad taxonomic group or category \\
\hline $\begin{array}{l}\text { Impact category (mandatory, } \\
\text { if relevant to paper) select } 1-\end{array}$ & \\
\hline
\end{tabular}

\section{SCHOLARONE ${ }^{\text {TH }}$ Manuscripts}


Title: Changing distribution of the east coast of Scotland bottlenose dolphin population and the challenges of area-based management.

Authors: Arso Civil, M. ${ }^{1 *}$, Quick, N.J. ${ }^{1, a}$, Cheney, B. ${ }^{2}$, Pirotta, E. ${ }^{2, b}$, Thompson, P.M. ${ }^{2}$, Hammond, P.S. ${ }^{1}$

${ }^{1}$ Sea Mammal Research Unit, Scottish Oceans Institute, University of St Andrews.

${ }^{2}$ Lighthouse Field Station, Institute of Biological and Environmental Sciences, University of Aberdeen.

\footnotetext{
a Duke University Marine Laboratory, Nicholas School of the Environment, Beaufort, NC, USA

${ }^{\mathrm{b}}$ Department of Mathematics and Statistics, Washington State University, Vancouver, Washington, USA and School of Biological, Earth and Environmental Sciences, University College Cork, Cork, Ireland
} 


\section{Abstract}

2 1. The efficacy of marine protected areas (MPAs) depends on clear conservation objectives and

3 ecologically meaningful boundaries. The east coast of Scotland bottlenose dolphin population

4 expanded its distributional range during the 1990s beyond the boundaries of the Special Area of

5 Conservation (SAC) in the Moray Firth, originally proposed to contain their core area of distribution.

6 Two decades on, this study assesses the importance for this population of St Andrews Bay and the

7 Tay estuary, $300 \mathrm{~km}$ south of the SAC.

8 2. Photo-identification data from 2009 to 2015 were analysed using mark-recapture models to

9 investigate the proportion of the population that uses St Andrews Bay and the Tay estuary. Habitat

10 models were fitted to bottlenose dolphin presence-absence data to identify areas of high use.

11 3. The estimated number of dolphins using St Andrews Bay and the Tay estuary during the summer

12 increased from 91 (95\% CI 78-106) in 2009 to 114 (95\% CI 95-137) in 2015, representing, on

13 average, $52.5 \%$ of the total estimated east coast population for that period. Spatial mixing of

14 individuals during the summer between St Andrews Bay and the Tay estuary and the Moray Firth

15 SAC was estimated to be a minimum of $\sim 6 \%$ per year and $\sim 30 \%$ over the study period. The entrance

16 to the Firth of Tay and waters around Montrose were identified as areas of consistent high use.

17 4. The importance of St Andrews Bay and the Tay estuary reconfirms that effective monitoring of the

18 population requires dedicated effort in both this area and the SAC. The results lead to consideration of

19 the wider context of area-based management for the conservation/management of highly mobile wide-

20 ranging species and human activities that might impact them.

24 Keywords: coastal, conservation evaluation, estuary, mammals, Special Area of Conservation. 
1. Introduction

The designation of marine protected areas (MPAs) is a widely advocated approach in the conservation of many marine taxa (Halpern, 2003; Hooker \& Gerber, 2004), supported under a number of conservation frameworks (e.g. Natura 2000 under the EU Habitats Directive (92/43/EEC); Convention on the Conservation of European Wildlife and Natural Habitats (1979); IUCN Important Marine Mammal Areas; Scottish Government MPA network) (Council of the European Communities, 1992; Council of Europe, 2018; Marine Mammal Protected Areas Task Force, 2018; Scottish Government, 2017). Area-based management approaches are intended to protect both the species of interest and other key components of the ecosystem, and their effectiveness relies in part on the ability to identify boundaries that are ecologically meaningful given the spatio-temporal distribution of the population of interest (Cañadas, Sagarminaga, De Stephanis, Urquiola, \& Hammond, 2005; Hooker \& Gerber, 2004) .

MPAs are typically designed with fixed boundaries, which present a challenge for the targeted conservation of highly mobile species, for migratory populations, for offshore oceanic species with extensive ranges that may vary seasonally and for more discrete populations that might still display wide ranging movements (Reeves, 2000; Wilson, 2016). The biological information leading to the designation of an MPA may be limited, and thus an adaptive approach during the early phases of management to incorporate information on the use of the MPA by the population of interest, as it becomes available, is recommended (Silva et al., 2012; Williams, Lusseau, \& Hammond, 2009).

For a species-based MPA to be effective, clear conservation objectives are needed for the focal population. These objectives may vary depending on the characteristics of the population and its interaction with anthropogenic activities within the area. Management actions could include restricting or banning certain activities to reduce mortality (Gerrodette \& Rojas-Bracho, 2011; Gormley et al., 2012) or to protect key life-history processes (Ashe, Noren, \& Williams, 2010; Williams et al., 2009). Monitoring the long-term effectiveness of an MPA is essential to assess how well it is meeting its objectives (Gormley et al., 2012; Rayment, Dawson, \& Slooten, 2010). 
51 Under a framework known as Natura 2000, the EU Habitats Directive (92/43/EEC) requires the

52 designation of Special Areas of Conservation (SACs) to make a significant contribution to the conservation of species listed under Annex II, which includes the bottlenose dolphin (Tursiops truncatus). As part of the UK's response, a candidate Special Area of Conservation (cSAC) in the inner Moray Firth (NE Scotland) was proposed in 1996 to protect the only known resident population of bottlenose dolphins in the North Sea. The cSAC boundary encompassed the core area of occurrence of the population as known at that time, based on data from the 1980s to the early 1990s (Curran, Wilson, \& Thompson, 1996; Mudge, Crooke, \& Barrett, 1984), and was eventually designated in 2005. During the 1990s, however, the population's distributional range expanded into areas to the south of the Moray Firth (Wilson, Reid, Grellier, Thompson, \& Hammond, 2004). Longsurveys or dolphin-watching boat tours occur in this region.

Current knowledge of the distribution, abundance and habitat use of bottlenose dolphins within the more limited (Cheney et al., 2013; Culloch \& Robinson, 2008; Quick, 2006; Weir, Canning, Hepworth, Sim, \& Stockin, 2008). During the range expansion (Wilson et al., 2004), surveys started 76 SAC is extensive, based on long-term monitoring over almost three decades (e.g. Cheney, Graham, Barton, Hammond, \& Thompson, 2018; Hastie, Wilson, \& Thompson, 2003; Pirotta et al., 2014; Wilson, Thompson, \& Hammond, 1997). Data from other areas of the main distributional range, including the southern outer Moray Firth, Aberdeenshire, and St Andrews Bay and the Tay estuary are 
population's main distributional range (Figure 1). Consistent dedicated surveys have been conducted in this area every year since 2009 , and have continued beyond the study presented here.

Under the Habitats Directive, each Member State must report every six years on the site condition of designated SACs, and on the Favourable Conservation Status in national waters for species listed under Annex IV, which includes all cetacean species. SAC site condition is assessed on the basis of a set of targets for specified attributes. The attributes of the Moray Firth SAC for bottlenose dolphins include the number of dolphins using the SAC and the frequency of occurrence of dolphins within the SAC. Atypically, a third attribute is trends in the population, with the target to maintain a stable or data from outwith the SAC were starting to become available. It was deemed expedient to formalize (recovered)" (Cheney et al., 2018). summarized as avoiding deterioration of the habitats of, or significant disturbance to, the bottlenose dolphins associated with the SAC (see Conservation Objectives document in SiteLink Scottish

102 Natural Heritage, 2018). Regulatory authorities are required to assess whether any planned development may have a significant effect on these conservation objectives. Because animals present 
104 in the SAC commonly occur along the east coast of Scotland to the south (Cheney et al. 2013; Quick 105 et al. 2014), connectivity is established throughout this main distributional range. Scottish Natural 106 Heritage guidance is therefore that any planned development that could affect bottlenose dolphins 107 anywhere within the population's range is likely to have a significant effect on the SAC and will 108 require an appropriate assessment (SNH Natura Casework Guidance, 2018). Examples of such 109 developments are the Aberdeen harbour expansion and the Forth and Tay windfarm developments 110 (Marine Scotland Information, 2018; Scottish Government, 2014). Thus, although Wilson et al. 111 (2004) suggested that the range expansion in the 1990s might potentially diminish the protection 112 originally envisioned for the Moray Firth SAC, the way in which the Habitats Directive is 113 implemented in this specific case means that the SAC effectively provides protection for the 114 population throughout its range.

115 Here the importance of St Andrews Bay and the Tay estuary for this population of bottlenose dolphins 116 is assessed, more than a decade after the population's range expansion was documented by Wilson et 117 al. (2004). To investigate the proportion of the population that uses this area, photo-identification data 118 collected during consistent dedicated surveys (2009 to 2015) in this area are analysed and compared 119 to data from this and other parts of the current main distributional range over the same time period. 120 These data are also used to estimate the minimum proportion of identifiable animals seen in both the 121 Moray Firth SAC and the St Andrews Bay and the Tay estuary area every summer and over the 20092015 study period. This provides some information on the spatial mixing of individuals across the population range and adds to current knowledge of the degree of connectivity of the population.

124 Habitat modelling techniques are applied to bottlenose dolphin presence-absence data collected during 125 surveys in 2012 and 2013 in St Andrews Bay and the Tay estuary to investigate a subset of available 126 environmental features that may explain relative abundance in this area and to identify areas of high use.

128 The implementation of Natura 2000 for the east coast of Scotland bottlenose dolphin population via 129 the Moray Firth SAC is envisaged to provide protection for the population throughout its range.

130 However, this is an atypical application of the Habitats Directive and, more generally, of area-based 
management, and this population provides an interesting basis for wider consideration. Therefore, the

132 results are discussed in the context of the conservation of highly mobile marine species that can range

133 widely, in general, with the intention that this may be informative to other situations involving area-

134 based management to help protect such species.

135 2. Methods

136 2.1 Data collection

137 Boat-based surveys were conducted off the east coast of Scotland between 2009 and 2015 in the

138 summer months (May to September) to collect photo-identification data of bottlenose dolphins.

139 Sampling effort was consistent (regular surveys throughout May-September) in all years in the two

140 main survey areas: St Andrews Bay and the Tay estuary (extending from Fife Ness to Montrose), and

141 the Moray Firth SAC (Figure 1). In other parts of the population's range, survey effort was variable

142 and more limited: in the outer Moray Firth fewer surveys occurred between 2009 and 2015, and in the

143 Firth of Forth and between Montrose and Aberdeen surveys only occurred in 2012 and 2013 (Figure

$1441)$.

145 Photo-identification data were collected following standardized protocols (see Cheney et al., 2014 for

146 details) during encounters with groups of bottlenose dolphins, defined as one or more individual

147 dolphins in close proximity and engaging in similar behaviour (e.g. traveling, foraging). Individual

148 dolphins were identified from high quality photographs (Wilson, Hammond, \& Thompson, 1999)

149 based on unique markings on the dorsal fin (Würsig \& Jefferson, 1990), and matched against a

150 catalogue of previously identified bottlenose dolphins from the east coast of Scotland (Cheney et al.,

151 2013). Capture histories of marked (i.e. dolphins with distinctive long-lasting nicks on the trailing

152 edge of the dorsal fin) individual dolphins were compiled to estimate the abundance of animals: (1)

153 using the sub-area of St Andrews Bay and the Tay estuary, and (2) using the population's main

154 distributional range (i.e. between the Moray Firth and the Firth of Forth, using photo-identification

155 data collected across the range including the outer Moray Firth, between Aberdeen and Montrose, and

156 the Firth of Forth) (Figure 1). To investigate the movements of animals between areas at the extremes

157 of the main range, St Andrews Bay and the Tay estuary to the south; and the Moray Firth SAC to the 
158 north, the number of marked individuals identified every summer, and over the study period in each

159 and both areas were compared.

160 Bottlenose dolphin presence/absence data collected during the photo-identification surveys conducted 161 in 2012 and 2013 in St Andrews Bay and the Tay estuary (Figure 1) were used to model habitat use. 162 Survey lines were designed to provide even coverage over a $1 \mathrm{~km}$ grid within each month. Effort was 163 divided into search effort (i.e. when following survey lines searching for dolphins) and follow effort 164 (during an encounter with dolphins). For the duration of each survey, the boat position, sea surface 165 temperature and depth were recorded in situ every minute using a Garmin GPS Map 551s

166 GPS/Plotter/Sounder and a temperature sensor. Data collection protocols were designed to minimize 167 any behavioural response of the encountered animals to the boat, i.e. attraction or avoidance. Bow 168 riding (i.e. attraction behaviour) was discouraged by reducing boat speed or completely stopping the 169 boat if necessary; the encounter was only resumed if/when animals where observed behaving 170 independently from the boat (e.g. traveling, foraging). If a group of dolphins split during an 171 encounter, a decision was made to follow the main group of dolphins followed up to that point in the 172 encounter. If the composition of the group changed substantially, a new encounter was started, 173 following the general photo-identification protocol. Finally, in the event of time/light constraints, both 174 search and follow effort were suspended, meaning any further presence/absence data were excluded 175 from the analysis.

$176 \quad 2.2$ Abundance of marked animals

177 Simple conventional mark-recapture models used to estimate abundance assume an equal probability 178 of capture among animals on any one sampling occasion (Hammond, 2010). The combination of a 179 large distributional range, limited sampling effort, and variability in the movement patterns among 180 individuals (Cheney et al., 2013) can result in individuals being available for sampling on some 181 occasions but not on others (i.e. temporary emigration; Kendall, Nichols, \& Hines, 1997), which may 182 introduce bias to estimates of animal abundance (Kendall, 1999). The robust design (RD) model 183 framework (Kendall et al., 1995, 1997; Pollock, 1982) combines open and closed population models 184 with estimators that incorporate temporary emigration to produce unbiased estimates of abundance, 
185 and has been increasingly applied in cetacean population studies (e.g. Cantor, Wedekin, Daura-Jorge, 186 Rossi-Santos, \& Simões-Lopes, 2012; Smith, Pollock, Waples, Bradley, \& Bejder, 2013; Verborgh et 187 al., 2009).

188 In our application of the RD model framework, each annual field season represented a primary 189 sampling occasion, and calendar months within each season (May to September), secondary sampling occasions. The latter provided a balance of adequate sample size within relatively short secondary sampling occasions separated by some days to allow mixing of the population. The RD applies closed population models to data from secondary sampling occasions (calendar months) within each primary sampling occasion (year) to derive estimates of capture probability $(p)$ and population size $(\hat{N})$. Open population models are applied to the data from primary occasions (years) to estimate the probability of apparent survival $(\varphi)$ and temporary emigration $\gamma^{\prime \prime}$ and $\gamma^{\prime}$, defined as the probabilities of an animal being outside the sampling area in a year conditional on it being inside or outside the sampling area, respectively, during the previous year. $\gamma^{\prime \prime}$ is thus the probability of temporary emigration and $1-\gamma^{\prime}$ is the probability of re-immigration. Temporary emigration can be random, in which the probability of emigrating does not depend on whether or not an animal was previously available $\left(\gamma^{\prime \prime}=\gamma^{\prime}\right)$, or Markovian, in which the probability of emigrating depends on whether or not an animal was previously available $\left(\gamma^{\prime \prime} \neq \gamma^{\prime}\right)$.

A candidate set of models was fitted to capture histories of dolphins for each defined sampling area (i.e. St Andrews Bay and the Tay estuary, and the population's main range). Survival was constrained to be constant in all models. Capture probabilities were allowed to vary between and within years because preliminary analysis showed less support for models restricting capture probabilities to be constant over the study period, or to vary among years but not among months. Models allowing for individual heterogeneity in capture probabilities were also included using Pledger (2000) mixture models, in which the population is assumed to comprise a mixture of two or more types of individuals with different probability of capture, defined by mixture parameters $(\pi)$. The number of types was limited to two to avoid over-parameterization of the models. Note that this does not imply that there

211 are actually two distinct types of animal, simply that the use of such a mixture can reduce bias caused 
212 by assuming homogeneity of capture probabilities (Pledger \& Phillpot 2008). Random and Markovian

213 temporary emigration parameters were allowed to be constant or time-dependent, with constraints

214 being applied to allow identifiability of parameters (Kendall et al., 1997). Models without movement (

$215 \gamma^{\prime \prime}=\gamma^{\prime}=0$ ) were also included.

216 There is no goodness-of-fit test available for the RD modelling approach. Instead, prior to model

217 fitting, program U-CARE (Choquet, Lebreton, Gimenez, Reboulet, \& Pradel, 2009) was used to

218 explore the key assumptions about the probability of capture (Lebreton, Burnham, Clobert, \&

219 Anderson, 1992) and to calculate the variance inflation factor ( $\hat{c})$, which is indicative of over-

220 dispersion of the data when $>1$ and can be used to adjust model statistics and confidence intervals

221 around the estimated parameters. To do so, data within each year from both data sets were pooled

222 together into single annual sampling occasions in a Cormack-Jolly-Seber (CJS) framework (e.g.

223 Pollock, Nichols, Brownie, \& Hines, 1990). The assumptions regarding the probability of capture

224 were satisfied in both data sets, and results found no evidence of over-dispersion in either of the two

225 data sets $(\hat{c}<1)$ so model selection was based on the Akaike Information Criterion (Akaike, 1973)

226 adjusted for small sample size (Burnham \& Anderson, 2002). Model structures and parameters were

227 specified and run using the package RMark (Laake, 2013) in R (R Core Team, 2016), and program

228 MARK (White \& Burnham, 1999).

229 2.3. Total abundance of animals

230 Estimates of abundance from mark-recapture models relate to animals with distinctive long-lasting

231 marks (marked animals) and must be inflated to the total number of animals (i.e. marked and

232 unmarked individuals) by the proportion of marked individuals in the population, $\theta$. Because

233 unmarked individuals may not be identified from both sides, $\theta$ was calculated separately for each side

234 as the number of marked individuals photographed from the right and the left sides in each trip

235 divided by the total number of individuals photographed from each side, respectively. Generalized

236 Linear Models (GLMs) with a binomial distribution and a logit link function were then fitted to data

237 from St Andrews Bay and the Tay estuary and to data from the population's main range to estimate

238 the annual proportion of marked individuals in each of the areas. In the models, the proportion of 
239 marked animals from both sides in each trip and area was the response variable and year was the 240 explanatory variable, to account for variations in the estimated proportion of marked animals from 241 year to year due to variation in sampling effort.

242 Estimates of the total number of animals, $\hat{\mathrm{N}}_{\text {total }}$, were calculated by dividing each estimate of annual 243 abundance of marked individuals $(\hat{\mathrm{N}})$ from the best RD model by the corresponding annual proportion 244 of marked individuals $(\theta)$ :

$$
\hat{\mathrm{N}}_{\text {total }}=\frac{\hat{\mathrm{N}}}{\theta}
$$

246 with variance derived using the delta method:

$$
\operatorname{var}\left(\hat{\mathrm{N}}_{\text {total }}\right)=\hat{\mathrm{N}}_{\text {total }}^{2}\left(\frac{\operatorname{var}(\hat{\mathrm{N}})}{\hat{\mathrm{N}}^{2}}+\frac{\operatorname{var}(\hat{\theta})}{\hat{\theta}^{2}}\right)
$$

248 Log-normal confidence intervals were derived for total abundance estimates following Burnham, 249 Anderson, White, Brownie, and Pollock (1987). The lower and upper limits of the $95 \%$ confidence 250 interval were calculated as $\hat{\mathrm{N}}_{\text {total }} / \mathrm{C}$ to $\hat{\mathrm{N}}_{\text {total }} \cdot \mathrm{C}$, where $\mathrm{C}$ is calculated as follows:

$$
C=\exp \left(1.96 \sqrt{\ln \left(1+\mathrm{CV}_{\mathrm{N}_{\text {total }}}^{2}\right)}\right)
$$

\subsection{Habitat use}

\subsubsection{Presence/absence data processing}

254 The GPS fixes taken every minute were used as the sample data to model the habitat use of bottlenose

255 dolphins. Only on-effort points were included in the analysis (i.e. during search and follow effort), 256 excluding all other points (off-effort). On-effort points included in the analysis were restricted to 257 favourable sighting conditions (Beaufort scale 0 to 3). All on-effort points recorded during follow 258 effort (i.e. during the collection of photo-identification data) were classed as $1=$ presence, and all 259 other on-effort points recorded during search effort were classified as $0=$ absence.

\subsubsection{Environmental data}


261 Values of available environmental variables were extracted for each GPS fix to use as covariates in

262 models of bottlenose dolphin presence. Depth was collected in situ at each GPS fix, and any missing

263 values were extracted from EDINA Marine Digimap, at a resolution of $200 \mathrm{~m}$ (SeaZone Hydrospatial

264 Bathymetry). Slope (average depth gradient, measured in degrees) and aspect (orientation of the slope

265 in degrees) were computed in Manifold (Manifold System Release 8.0, 2013). Sediment type was

266 provided as a categorical variable by EDINA Geology Digimap / British Geological Survey and re-

267 classified into four new categories: rock, sand, muddy-sand, and gravelly sediment. The shortest

268 distance to land and to the entrance of the Tay estuary were computed in Manifold. Sea surface

269 temperature (SST) was collected in situ, and any missing values were averaged from all available in

270 situ temperature values taken in that same month within a $500 \mathrm{~m}$ cell around the missing value. Four

271 categories were defined for tidal state (low, rising, high, and falling), each representing a 3 hour block

272 of the tide cycle, based on tidal data extracted from POLTIPS-3 (Version 3.4.0.3/10, Proudman

273 Oceanographic Laboratory Applications Group) for the nearest tidal port to each GPS fix. Current

274 speed, level and direction were obtained using POLPRED (NERC National Oceanography Centre,

275 Liverpool, UK). Tidal data sourced from POLPRED were not available in areas very close to the

276 coast due to limitations of the tidal model to predict in those locations. Consequently, a subset of the

277 presence/absence data excluding missing values for tidal covariates was used to model the presence of

278 bottlenose dolphins. Year and month were also included as potential covariates in order to investigate

279 temporal variation in the probability of presence of bottlenose dolphins across years and months.

$280 \quad$ 2.4.3. Modelling approach

281 The presence/absence of bottlenose dolphins was modelled at each GPS fix using Generalized

282 Additive Models (GAMs) (Wood, 2006), with a binomial distribution for the error structure and a

283 logit link function. Following the analytical approach developed in Pirotta, Matthiopoulos,

284 MacKenzie, Scott-Hayward, and Rendell (2011), autocorrelation in GAM residuals was visualized by

285 means of an autocorrelation function (ACF) plot. Preliminary analysis showed that sub-setting the

286 data (i.e. data-thinning) did not eliminate the autocorrelation in GAM residuals. Instead, Generalized

287 Estimating Equations (GEEs) (Liang \& Zeger, 1986) were used to account for the observed 
288 autocorrelation. Models were fitted using the R library geepack (Halekoh, Højsgaard, \& Yan, 2006) 289 together with the library splines (Bates \& Venables, 2012) to extend the GEE-GLMs to GEE-GAMs.

290 Presence/absence data points were grouped into follow (i.e. consecutive presence points) and 291 searching (i.e. consecutive absence points) blocks, and a correlation structure within block was 292 selected based on the quasi-likelihood under the independence model criterion (QIC; Pan, 2001). 293 Multicollinearity among the covariates was inspected by means of Pearson's correlation coefficients 294 and generalized variance inflation factors (GVIF). Non-categorical covariates could enter the models 295 as a linear term, as a B-spline with four degrees of freedom (d.f.) (with one internal knot at the 296 average value of that covariate) or as a B-spline with five d.f. (with two internal knots, positioned at 297 the lower and upper quartiles of that covariate), and the $\mathrm{QIC}_{\mathrm{u}}$ (an approximation of the QIC; Pan, 298 2001) was used to compare the different forms. A manual backwards stepwise selection based on the 299 QIC $_{\mathrm{u}}$ was used to select the best subset of covariate predictors to model the presence of bottlenose 300 dolphins.

301 All covariates retained in the final model based on the $\mathrm{QIC}_{\mathrm{u}}$, improved the model fit and were thus 302 used to predict the presence of bottlenose dolphins. The goodness-of-fit of the final model was 303 evaluated by a confusion matrix of observed and predicted bottlenose dolphin presence/absence 304 values (Fielding \& Bell, 1997), shown as the percentage of correctly classified presences/absences by 305 the fitted model. The cut-off probability for classification was chosen based on a receiving-operating 306 characteristic (ROC) curve (Pearce \& Ferrier, 2000; Pirotta et al., 2011; Praca, Gannier, Das, \& 307 Laran, 2009). The ROC curve evaluates the proportion of correctly and incorrectly classified 308 predictions over a range of thresholds (Swets, 1988; Zweig \& Campbell, 1993), and the area under the 309 ROC curve (AUC) provides a measure of overall accuracy of model predictions (Boyce, Vernier, 310 Nielsen, \& Schmiegelow, 2002). The library 'ROCR' (Sing, Sander, Beerenwinkel, \& Lengauer, 3112005 ) was used to build the ROC curve plot, calculate the AUC and extract the best cut-off 312 probability, and the library PresenceAbsence (Freeman \& Moisen, 2008) was used to compute the 313 confusion matrix. Additionally, the significance of each retained covariate in the best model was 
314 assessed using repeated Wald's tests (Hardin \& Hilbe, 2003; Zuur, Ieno, Walker, Saveliev, \& Smith,

315 2009) by excluding the least significant covariate each time ( $p$-value $>0.05$ ).

316 To visualize the results, the final model was used to predict the probability of presence of bottlenose

317 dolphins in the sampling area, based on a $1 \mathrm{~km}$ cell grid with associated values for the retained

318 covariates. Values of dynamic covariates (e.g. tidal covariates) were averaged for each cell at the

319 temporal scale of interest retained in the final model (e.g. tidal state, month, or year), to generate

320 prediction maps of the presence of dolphins at different temporal scales. The presence of dolphins at

321 each location was predicted on the response scale (i.e. a value between 0 and 1 ) using the function

322 'predict' in R, and visualized by means of a smoothed surface of probabilities across the area.

323 3. Results

324 3.1. Photo-identification data

325 A total of 254 photo-identification surveys were conducted between 2009 and 2015 across the

326 population's main distributional range, of which 79 surveys occurred in St Andrews Bay and the Tay

327 estuary (Table 1). Overall, there were 1,139 encounters of bottlenose dolphin groups, of which 275

328 occurred in St Andrews Bay and the Tay estuary. Good quality photographs resulted in the

329 identification of 128 marked dolphins of which, 82 were identified in St Andrews Bay and the Tay

330 estuary between 2009 and 2015, with 33 to 52 individuals identified annually (Table 1).

331 The total number of animals identified in the sub-areas of St Andrews Bay and Tay estuary and/or the

332 Moray Firth SAC in any given year ranged between 74 and 99 over the study period (Table 2). Of

333 these, between $34.8 \%$ and $46.5 \%$ were seen only in St Andrews Bay and the Tay estuary (i.e. not seen

334 in the same year in the Moray Firth SAC) and 47.5\% to $57.1 \%$ were seen only in the Moray Firth

335 SAC (Table 2 and Figure 2). On average, 5.6\% (range $0 \%$ to $10.9 \%$ ) of the total number of marked

336 animals were seen in both areas in any one year, with no overlap in 2014. Over the study period,

$33735.2 \%$ of the marked animals were seen only in St Andrews Bay and the Tay estuary, $35.9 \%$ were

338 seen only in the Moray Firth SAC, and $28.9 \%$ were seen in both areas.

339 3.2. Abundance of animals 
340 For the population's main range dataset, model selection favoured models incorporating Pledger

341 (2000) heterogeneity mixture parameters over models without it (Table 3), out of 18 candidate

342 models. The most supported model, based on the lowest $\mathrm{AIC}_{\mathrm{c}}$ value, included time-varying

343 heterogeneity mixture parameter and time-varying random temporary emigration, with an average

344 probability of emigrating of 0.017 (range 0.00 to 0.044 ). The annual proportion of marked individuals

345 ranged between $0.49(\mathrm{CV}=0.028)$ and $0.55(\mathrm{CV}=0.023)$ for encounters in the population's main

346 range (Table 4). Once scaled up by the estimated annual proportion of marked individuals, the

347 estimated total number of bottlenose dolphins using the population's main distributional range varied

348 from 165 (95\% CI 156-175) animals in 2009 to 209 (95\% CI 189-230) in 2015 (Table 4).

349 For the St Andrews Bay and the Tay estuary dataset, models incorporating constant temporary

350 emigration (random and Markovian) and no-movement models received some support from the data

351 (Models 9 to $12, \Delta \mathrm{AICc}<4$, Table 3). The most supported model, representing half of the AICc

352 weight, included random temporary emigration, with a low constant probability of emigrating of

3530.106 (95\% CI 0.056-0.192) and time-varying heterogeneity mixture parameter (model 9 in Table 3).

354 The annual proportion of marked individuals in St Andrews Bay and the Tay estuary ranged between

$3550.47(\mathrm{CV}=0.087)$ and $0.52(\mathrm{CV}=0.051)($ Table 4$)$. Once scaled up by the estimated annual

356 proportion of marked individuals, the estimated total number of bottlenose dolphins using St Andrews

357 Bay and the Tay estuary ranged from a minimum of 85 (95\% CI 77-93) animals in 2011 to a

358 maximum of 121 (95\% CI 84-173) animals in 2014 (Table 4). On average, the estimated number of

359 animals using St Andrews Bay and the Tay estuary represented 52.5\% percent of the estimated total

360 population (i.e. using the population's main range).

361 3.3. Habitat use

362 3.3.1. Habitat model fitting, selection and evaluation

363 In total, 3,782 km of survey effort were conducted in 2012 and 2013 during the photo-identification

364 surveys in St Andrews Bay and the Tay estuary. Bottlenose dolphins were encountered 128 times,

365 resulting in $325 \mathrm{~km}$ of follows (Table 5). The resulting subset of data excluding data with missing 
366 values for tidal covariates included 7,758 GPS fixes with 2,739 presence points and 5,019 absence

367 points, grouped into 120 follow (presence) blocks and 185 searching (absence) blocks.

368 A full model with all available explanatory variables did not show signs of multicollinearity (GVIF <

369 2). A working independence structure was preferred to an autocorrelation structure of order 1 (AR1)

370 or to an exchangeable autocorrelation structure based on QIC values. The manual backwards stepwise

371 selection based on the $\mathrm{QIC}_{\mathrm{u}}$ retained distance to the Tay, current speed, current direction, temperature,

372 month and year in the final model. Dolphin presence increased close to the entrance of the Tay

373 estuary, and decreased away from it except for a second presence peak $30 \mathrm{~km}$ away, corresponding to

374 the waters around Montrose (Figure 3a). Predicted dolphin presence increased with current direction

375 flowing towards the NE (i.e. 10 to 60 degrees) or towards the WSW (i.e. 220 to 300 degrees) (Figure

$3763 \mathrm{~b}$ ), associated with higher current speeds based on the tidal data. A higher probability of presence of

377 bottlenose dolphins was associated with the lowest $(0.0$ to $0.15 \mathrm{~m} / \mathrm{s})$ and highest $(0.5$ to $0.8 \mathrm{~m} / \mathrm{s})$

378 current speeds occurring in St Andrews Bay and the Tay estuary during data collection for this study

379 (Figure 3c). The probability of dolphin presence was slightly higher in September, when SST was

380 between 12 and 15 degrees and in 2012 (Figures 3d-e-f). The 95\% confidence intervals around the

381 modelled relationships between the response variable and the retained covariates were generally wide.

382 The final model correctly predicted $70 \%$ of the presence/absence observations and the area under the

383 ROC curve was 0.741 , which is indicative of good performance of the final model (AUC $>0.7$ ).

384 Repeated Wald's test confirmed that the presence of dolphins was significantly related to distance to 385 the Tay $(p$-value $<0.05)$.

386 3.3.2. Predicted presence of bottlenose dolphins

387 The probability of presence of dolphins was predicted at different range values of the retained tidal

388 covariates (current speed and direction). Based on the visual inspection of the raw tidal data and the 389 modelled relationships between the probability of presence of dolphins and those two tidal covariates

390 (Figure 3b-c), current direction was divided into 10 to 60 degrees, 60 to 220 degrees, 220 to 300

391 degrees, and 300 to 10 degrees, and current speed was divided into 0 to $0.15 \mathrm{~ms}^{-1}, 0.15$ to $0.5 \mathrm{~ms}^{-1}$,

392 and $>0.5 \mathrm{~ms}^{-1}$. Values for each combination of current speed and current direction were averaged for 
393 each $1 \mathrm{~km}$ grid cell. SST was averaged across months, and the year and month with the highest

394 coefficient values were selected for the predictions.

395 The prediction maps identified the entrance of the Tay as an area with high probability of presence of 396 bottlenose dolphins in all value ranges of current direction and current speed (Figures 4 and 5). The 397 area around Montrose was also predicted to have a high probability of presence of bottlenose 398 dolphins, while the southern half of St Andrews Bay and the waters between Carnoustie and north of 399 Arbroath had a lower probability of presence of dolphins. Within those identified areas of high 400 probability of dolphin presence, the prediction maps showed that dolphin presence was lowest when 401 the tidal flow was between 60 and 220 degrees and that the area with higher predicted probability of 402 dolphin presence shifted slightly along the entrance to the Tay estuary at different current directions 403 (Figure 4). The entrance of the Tay was identified as a high probability of dolphin presence at the 404 highest current speeds $\left(>0.5 \mathrm{~ms}^{-1}\right)$. Bottlenose dolphins were predicted to be present at the entrance to 405 the Tay and around Montrose even at the lowest current speeds ( 0 to $\left.0.15 \mathrm{~ms}^{-1}\right)$ (Figure 5).

406 4. Discussion

407 At the time the SAC for bottlenose dolphins on the east coast of Scotland was proposed, the only 408 known concentration of animals was in the Moray Firth. However, during the 1990s, the population 409 expanded its distributional range to areas outside the Moray Firth (Wilson et al., 2004). Here it is 410 shown, more than a decade after Wilson et al. (2004) documented the range expansion, that St 411 Andrews Bay and the Tay estuary was consistently used by half of the estimated population every 412 summer. Furthermore, over the entire 2009-2015 period, around one-third of the population was seen 413 only in this area, $300 \mathrm{~km}$ from the Moray Firth SAC. The results also show that dolphin presence in 414 this area is focused on the entrance to the Firth of Tay and waters around Montrose.

415 4.1. Population context of St Andrews Bay and the Tay estuary

416 The estimated total population over the 7-year period was variable, but increased from 165 (95\% CI

417 156-175) animals in 2009 to 209 (95\% CI 189-230) in 2015. This estimate of an increasing

418 population, from robust design analyses making use of data at a finer temporal scale within years from 
419 across the population's range, confirms previous work by Cheney et al. (2018) that used annual

420 summaries of these sightings within a state space population model. Recent work by Arso Civil et al.

421 (in press) identified an increase in juvenile and adult survivorship in this population, most likely

422 driven by a change in juvenile survival, and Cheney (2017) found an increasing trend in reproductive

423 rates and in calf survival for animals using the Moray Firth SAC. These results appear to explain the

424 population's overall increase in size (Cheney et al., 2018) and may be a result of the previous range

425 expansion (Wilson et al., 2004). It remains unknown, however, whether there is an influence of area

426 on survival and fecundity rates. To explore this, especially in the context of the importance of St

427 Andrews Bay and the Tay estuary identified in this study, annual data collection in both areas is

428 required.

429 The estimated abundance of dolphins using St Andrews Bay and the Tay estuary during the summer 430 over the same period was also variable and, similarly, increased overall from 91 (95\% CI 78-106) in 4312009 to 114 (95\% CI 95-137) in 2015. The percentage of the total population using St Andrews Bay 432 and the Tay estuary in summer during 2009-2015 averaged 52\%. The percentage of the population 433 using the Moray Firth SAC in summer declined from 2001 to 2015 but averaged more than 50\% over 434 this period (Cheney et al., 2018). The percentage of marked animals seen only in one area or the other 435 during 2009-2015 was also equivalent at 35\%. These results lead us to conclude that the St Andrews 436 Bay and Tay estuary area is equally as important, in terms of simple presence of individuals, to the 437 population in summer as the Moray Firth SAC. Assessing the importance of these (and other) areas in 438 terms of how individuals use them temporally and spatially requires further work.

439 Animals in this population are highly mobile across the population's main distributional range and 440 also show high individual variability in movement patterns, both spatially and temporally (Cheney et 441 al., 2013; Quick et al., 2014). Analysis of photo-identification data collected across the population's 442 main distributional range in 2006 and 2007 showed that the number of individuals seen in more than 443 one area varied spatially, with the highest numbers between the geographically closest areas (within 444 the Moray Firth) and lowest between the most distant ones (between the Grampian /Fife coast, where 445 St Andrews Bay and the Tay estuary are located, and the Moray Firth SAC) (Cheney et al., 2013). 
446 Comparison of photo-identification data collected from 1997 to 2007 in St Andrews Bay and the Tay

447 estuary and in the Moray Firth SAC has shown that some animals were present in both areas within a

448 single summer and others were present in one area for one or more years before being sighted in the 449 other area the next year(s) (Quick et al., 2014).

450 The results show that the percentage of marked dolphins observed in both the Moray Firth SAC and in 451 St Andrews Bay and the Tay estuary is small (average 5.6\%) in any single summer and that during the 4527 -year study period fewer than $30 \%$ of these marked animals were seen in both areas, while around $453 \quad 35 \%$ were seen only in St Andrews Bay and the Tay estuary and 35\% only in the SAC.

454 Making inferences from these results about spatial mixing of individuals in the population is limited 455 by the fact that photo-identification effort included in this study only occured in certain areas within 456 the population's main distributional range, leaving other areas such as between the outer Moray Firth 457 and Aberdeen with no information on the spatio-temporal presence of individuals from the 458 population. Given the extensive distributional range, and in accordance with differences in individual 459 movements between close and distant areas within the range (Cheney et al., 2013), it is conceivable 460 that there is a cline in individual ranging behaviour.

461 Making inferences about spatial mixing at the population level also requires making two technical 462 assumptions. First, it needs to be assumed that marked individuals are representative of the 463 population. Bottlenose dolphins acquire permanent markings with age and males acquire more marks 464 than females (e.g. Marley, Cheney, \& Thompson, 2013) so bias could be introduced if younger 465 animals and/or females are more or less likely to move between these two areas. In an analysis of data 466 including animals with and without long-lasting permanent marks, Quick et al. (2014) found patterns 467 that suggested a tendency for males to move more frequently than females between the Moray Firth 468 SAC and St Andrews Bay and the Tay estuary. The inclusion of animals without long-lasting 469 permanent marks in this analysis makes it difficult to make clear comparisons with our results and it 470 remains unknown whether the results for animals with long-lasting permanent marks are 471 representative of the population. 
472 Second, it needs to be assumed that individuals seen in both areas in a summer season have the same

473 probability of being observed (captured) as individuals seen in only one area or the other. Capture

474 probability over an entire summer is very high in St Andrews Bay and the Tay estuary and in the

475 Moray Firth SAC. Over the period 2009-2015, annual capture probability (calculated simply as

476 number of marked animals observed divided by estimated total number of marked animals) varied

477 from 0.88 to 1.0 in St Andrews Bay and the Tay estuary, except in 2014 (0.58), and from 0.91 to 0.98

478 in the Moray Firth SAC (Cheney et al., 2012, 2018). Nevertheless, it is possible that the number of

479 animals seen in both areas may be greater if capture probability is higher. The number seen in both

480 areas each summer was positively correlated with capture probability in St Andrews Bay and the Tay

481 estuary but negatively correlated with capture probability in the Moray Firth SAC. We conclude that

482 any bias introduced by variation in capture probability is likely to be small.

483 If these assumptions are met, the results indicate that individuals within the population display

484 differential use of these areas within the population's main distributional range, at least in summer. To

485 extrapolate beyond the summer, it has to be assumed that the observed levels of spatial mixing of

486 individuals are similar at other times of the year. There are few photo-identification data outside the

487 summer months, primarily because of adverse conditions for surveys. Incidental sightings of dolphins

488 along the Fife coast (including St Andrews Bay, the Tay estuary and the Firth of Forth) are recorded

489 throughout the year, and acoustic data have shown that bottlenose dolphins are present between the

490 Moray Firth and St Andrews Bay in winter (Thompson et al., 2011). But it remains unknown whether

491 the levels of spatial mixing of individuals observed in summer are representative of the whole year.

492 Information about the spatial mixing of individuals over the range of a population has potential

493 implications for conservation, as described above. The overall connectivity within the east coast of

494 Scotland bottlenose dolphin population is well-established. The results presented here provide a rough

495 approximation of the temporal scale at which that connectivity operates. Assuming that the level of

496 spatial mixing of individuals observed in summer is representative of the whole year and remains the

497 same over time, a crude extrapolation of the $28.9 \%$ of animals seen in both areas over the 7 -year study

498 period implies that it would take around 25 years, about a generation (assuming 21 years, Taylor, 
499 Chivers, Larese, \& Perrin, 2007), for the population to mix completely over its range. This supports

500 the need to continue to obtain data from both areas to monitor the population effectively and gives an 501 indication of the temporal scale at which the impact of human activities in one area may be manifest 502 in the other area.

503 4.2. Identification of high use areas

504 Bottlenose dolphins were seen in all surveyed months (May to September) in 2012 and 2013, when 505 bottlenose dolphin presence/absence data were collected, in line with the rest of the surveyed 506 summers in this study and past survey effort during the summer in St Andrews Bay and the Tay 507 estuary (Cheney et al., 2013). However, the predicted presence of bottlenose dolphins was not 508 uniform across the study area. In particular, the models identified high use areas at the entrance of the 509 Firth of Tay and in the waters around Montrose. The sandwich-based variance estimators used in the 510 GEEs produced robust standard errors which ensured the retained covariates in the final model based 511 on the $\mathrm{QIC}_{\mathrm{c}}$ were important predictors of dolphin presence (Hardin \& Hilbe, 2003). Interpretation of 512 the relationship between dolphin presence and the retained covariates in the final model was however 513 difficult given the resulting wide 95\% confidence intervals (e.g. Pirotta et al., 2011), and suggest a 514 much more complex picture. Despite these limitations, the resulting prediction maps identified these 515 high use areas consistently across different current speeds and current directions.

516 Temporal and spatial variability in the presence of bottlenose dolphins off the east coast of Scotland 517 has previously been discussed in the context of the availability of food resources (Bailey, Corkrey, 518 Cheney, \& Thompson, 2013; Hastie, Wilson, Wilson, Parsons, \& Thompson, 2004; Mendes, Turrell, 519 Lutkebohle, \& Thompson, 2002). In the Moray Firth, the peak in bottlenose dolphin presence in the 520 summer months coincides with seasonal migrations of salmonids (Atlantic salmon Salmo salar and 521 sea trout Salmo trutta) through the area (Wilson et al., 1997). Salmonids are known to be important 522 prey for bottlenose dolphins based on the analysis of stomach contents (Santos et al., 2001), and direct 523 observations of foraging events (Hastie et al., 2004; Janik, 2000; Wilson et al., 1997). During the 524 course of this study bottlenose dolphins were also observed foraging on salmonid species, as well as 525 flatfish and mackerel, in St Andrews Bay and the Tay estuary. Other prey species important in the diet 
526 of bottlenose dolphins from this population include cod, saithe, whiting, haddock and cephalopods

527 (Santos et al., 2001), all found in the waters off south-east Scotland (Callaway et al., 2002).

528 The river Tay and the rivers North Esk and South Esk by Montrose are important for migrating

529 salmon and sea trout in Scotland (ASFB \& RAFTS, 2014; Marine Scotland Science, 2012), and

530 salmon and sea trout that do not migrate upstream also approach the Tay estuary at different stages of

531 their life cycle (Mills, 1986). It is thus likely that salmonids are an important prey species for

532 bottlenose dolphins in these areas, at least during the summer months, as has also been found for

533 harbour seals in the Tay estuary in summer and autumn, albeit with high uncertainty (Sharples,

534 Arrizabalaga, \& Hammond, 2009).

535 Tidal dynamics influenced dolphin presence, which varied at different current speeds and directions.

536 Because these covariates vary together throughout the tidal cycle, it is impossible to completely

537 separate their effect on the predicted dolphin presence. Dolphins were more likely to be present in

538 areas with low or high current speeds, compared to intermediate values, and when the current was

539 flowing approximately towards the NE or WSW (falling and rising tides), but also towards the NNW.

540 There is dynamic and complex tidal mixing at the entrance to the Tay estuary, influenced by offshore

541 tidal currents and by the estuarine currents, which have different phase relationships with respect to

542 high water (Ferrier \& Anderson, 1997). The outer part of the Tay estuary channel is characterized by

543 depths that range from 2 to 20 metres, with a generally flat sea bed $\left(0^{\circ}\right.$ to $3^{\circ}$ slope $)$. The entrance to

544 the channel is delimited by two sandbars about $1 \mathrm{~km}$ apart which are exposed at low tide. Thus,

545 despite the relatively shallow waters and a flat sea bed, the area experiences fast and complex tidal

546 currents (Ferrier \& Anderson, 1997), reaching spring tidal flows greater than $1.2 \mathrm{~ms}^{-1}$ and a spring

547 tidal range of 4.4 meters at the entrance to the Tay (Hansom et al., 2011).

548 There is no fine-scale information on the distribution and availability of bottlenose dolphin prey at the

549 entrance of the Tay estuary. However, this dynamic and complex tidal mixing may accumulate prey

550 and improve the foraging efficiency of dolphins in the area, as suggested for the narrow channels in

551 the inner Moray Firth with similar highly complex tidal dynamics (e.g. Bailey \& Thompson, 2006;

552 Hastie et al., 2004; Mendes et al., 2002). The sandbars may also increase foraging efficiency at low 
553 tide by confining and concentrating prey in the area or acting as a physical barrier that the dolphins 554 can use to herd fish. During the course of this study, individual dolphins were observed on many 555 occasions next to the exposed sandbar, especially on the south side of the estuary entrance, displaying 556 feeding behaviour (i.e. long dives at the same spot, chasing prey underwater, tossing fish at the 557 surface and/or with fish in their mouths). Individuals were also seen over or next to the sandbar at 558 other stages of the tide when it was covered by water.

559 A large proportion of the population uses both St Andrews Bay and the Tay estuary and the Moray 560 Firth SAC in the summer months (see above) and high use areas have been identified in both areas.

561 However, further work is required to assess the relative importance of specific areas across the 562 population's main range.

563 4.3. Wider-context considerations of area-based management

564 Wilson (2016) has discussed the limitations of area-based management for highly mobile, wide-

565 ranging species such as cetaceans and questioned some of the reasons behind its implementation; that 566 is, whether it is the right tool for these species. Nevertheless, protected areas in the form of SACs are 567 a legal requirement under the Habitats Directive for bottlenose dolphin and harbour porpoise and this 568 is the primary management framework that is used in Europe to protect these species. The case of the east coast of Scotland population of bottlenose dolphins is an interesting and potentially informative example of how the challenges of imposed area-based management have been tackled.

The SAC proposed in 1996 in the Moray Firth encompassed the core area of occurrence of the population as known at that time. During the range shift in the 1990s (Wilson et al., 2004), research to study the population in southern parts of its range increased. As described above, the availability of new data outwith the SAC led to a change in the attributes and targets for the SAC so that the additional data fed into the site condition assessment to evaluate population trends. This paper, using data from regular surveys in St Andrews Bay and the Tay estuary since 2009, shows that half of the

577 population uses this area every summer, with incomplete spatial mixing of individuals in the short

578 term between this area and the Moray Firth SAC. This re-confirms that assessing the conservation 579 status of the east coast of Scotland bottlenose dolphin population requires data from across the 
580 population range. Because the population is highly mobile within its main distributional range,

581 Scottish Natural Heritage guidance is that a planned development that could impact bottlenose

582 dolphins anywhere within the population's range is likely to have a significant effect on the SAC in

583 view of its conservation objectives and that such plans need to be considered in appropriate

584 assessments under Article 6 of the Habitats Directive (SNH Natura Casework Guidance, 2018).

585 Thus, although Wilson et al. (2004) suggested that the range expansion in the 1990s might diminish

586 the protection originally envisioned for the Moray Firth SAC, the way in which Natura 2000 is

587 implemented under the Habitats Directive in this specific case means that the SAC provides

588 protection for the population throughout its range, and not just in the relatively small Moray Firth

589 SAC. This management approach can therefore be seen as an effective way of maintaining favourable

590 conservation status for this particular population.

591 However, this is not really area-based management as conventionally considered. Article 3 of the

592 Habitats Directive states that: "For aquatic species which range over wide areas, such sites [SACs]

593 will be proposed only where there is a clearly identifiable area representing the physical and

594 biological factors essential to their life and reproduction". It is therefore clear that SACs should be in

595 areas that are important to a population. However, as described above, they are also a proxy for

596 monitoring and protecting the entire population if there is connectivity between SACs and the rest of

597 the population's range. The photo-identification techniques used to study the east coast of Scotland

598 bottlenose dolphin population demonstrate connectivity of individuals across the population's range.

599 In this sense, the location of the SAC is not critical because the same level of protection exists across

600 that range. As long as a site met the definition above, i.e. it was located in an area important to the

601 population and connectivity between the site and the rest of the range was demonstrated, the SAC

602 could be anywhere in the population's range and the same protection would result. The site condition

603 of the Moray Firth SAC is favourably assessed because it meets the targets of the attributes regarding

604 the use of the SAC by the population, even though the proportion of the population using the SAC is

605 declining (Cheney et al., 2018). This further illustrates that it is not just the SAC itself that is of

606 primary importance but the way in which the SAC management framework is implemented to protect 
607 the entire population. That half the population is observed in St Andrews Bay and the Tay estuary

608 each summer confirms that protecting the population everywhere is more important than protecting an 609 area at one end of the population's range.

610 The results presented here confirm that the east coast of Scotland population of bottlenose dolphins 611 has shown a marked change in distribution. These new analyses further support Cheney et al.'s (2018)

612 findings that the population is increasing, and raise the possibility that it is continuing to expand and 613 further shift its distribution, supported by recently increasing sightings of bottlenose dolphins south of 614 the Firth of Forth. Estimates of the number of animals using St Andrews Bay and the Tay estuary 615 have increased at around 5\% per year $(\mathrm{p}=0.0157)$ between 2009 and 2015. Although there is no 616 significant trend in the number of animals using the Moray Firth SAC in the same period, if there is a 617 southerly drift in the population in future it may be pertinent to consider whether current management 618 still provides adequate protection.

619 It is also worth considering how the way in which the east coast of Scotland population of bottlenose 620 dolphins is assessed and protected may be relevant to the conservation of other populations of highly 621 mobile wide-ranging species. For example, the UK and Scottish governments recently proposed a 622 number of SACs for harbour porpoise (JNCC, 2017; Scottish Government, 2016), a widely distributed 623 species in shelf waters of the European Atlantic (Hammond et al., 2013) and the only other species of cetacean requiring SACs under Natura 2000. Population-wide photo-identification of harbour porpoises is unfeasible but telemetry studies have provided some indications of connectivity of 626 individuals (Sveegaard et al., 2011, 2015). The proposed SACs in UK waters are large, reflecting the 627 highly-mobile wide-ranging nature of the species and they cover a large proportion of English and 628 Welsh waters over which connectivity of individuals may reasonably be assumed. Thus, monitoring 629 and management equivalent to that implemented for the Moray Firth SAC for bottlenose dolphins 630 may allow assessment of conservation status and provide protection for harbour porpoise throughout 631 most of its range in these waters. However, this is unlikely to be true in Scottish waters because the 632 single SAC west of Scotland is far from the majority of the distribution of harbour porpoises around 
633 the Northern Isles and east of Scotland, where there is no proposed SAC, and connectivity of

634 individuals could not reasonably be assumed.

635 The conclusion here is that management using SACs as a proxy for monitoring and protecting highly

636 mobile wide-ranging populations is only likely to succeed if the SACs cover a large proportion of the

637 population distribution and that connectivity of individuals throughout the distributional range can be established. This has been feasible for the bottlenose dolphin populations using photo-identification

639 data but the lack of knowledge about the connectivity within other populations of highly mobile

640 species, including most cetaceans and seabirds, means that area-based management to conserve

641 populations remains a considerable challenge.

642 Spatial and temporal variability in cetacean distributions poses challenges in the designation of 643 protected areas (e.g. Embling et al., 2010) and calls for a flexible approach and adaptive management 644 to ensure continued effectiveness of protected sites (Rayment et al., 2010; Silva et al., 2012). Area645 based conservation/management of highly mobile wide-ranging species and human activities that 646 might impact them can be effective, as illustrated by how it is applied to the east coast of Scotland 647 bottlenose dolphin population. But whether this approach is generally the most appropriate way to 648 monitor and protect populations of such species is not clear, for the reasons outlined by Wilson 649 (2016). Monitoring over the main distributional range is clearly needed but the way in which 650 anthropogenic pressures and threats are managed needs to be considered carefully.

\section{Acknowledgments}

652 MAC received funding from the Department of Energy and Climate Change (DECC) (now 653 Department for Business, Energy and Industrial Strategy) UK, and the MASTS (Marine Alliance for 654 Science and Technology for Scotland) pooling initiative. MASTS is funded by the Scottish Funding 655 Council (grant reference HR09011) and contributing institutions. Annual surveys were funded by 656 DECC, Scottish Natural Heritage (SNH), Beatrice Offshore Windfarm Ltd., Moray Offshore 657 Renewables Ltd, Marine Scotland, The Crown Estate, Highlands and Islands Enterprise and the 658 Universities of St Andrews and Aberdeen. All fieldwork was carried out under SNH Animal 659 Scientific Licences to PMT and PSH. The authors have no conflict of interest to declare. 
660 We thank John Baxter for helpful discussions about the implications for conservation and 661 management while drafting this manuscript, and Morven Carruthers for her advice on the site

662 condition monitoring for the Moray Firth SAC. This manuscript benefited from the helpful comments 663 of two anonymous reviewers.

\section{References}

665 Akaike, H. (1973). Information theory and an extention of the maximum likelihood principle. Second 666 International Symposium on Information Theory, 267-281.

667 Arso Civil, M., Cheney, B., Quick, N. J., Islas-Villanueva, V., Graves, J. A., Janik, V. M., .. . 668 Hammond, P. S. (in press). Variations in age- and sex-specific survival rates help explain 669 population trend in a discrete marine mammal population. Ecology and Evolution 670 ASFB \& RAFTS. (2014). Association of Salmon Fishery Boards (ASFB) and Rivers and Fisheries 671 Trusts of Scotland (RAFTS) 2014 Annual Review. Retrieved from http://www.asfb.org.uk/wp-content/uploads/2014/03/ASFB-RAFTS-Annual-Review2014.pdf

Ashe, E., Noren, D., \& Williams, R. (2010). Animal behaviour and marine protected areas: incorporating behavioural data into the selection of marine protected areas for an endangered killer whale population. Animal Conservation, 13(2), 196-203.

Aynsley, C. L. (2017). Bottlenose dolphins (Tursiops truncatus) in north-east England: A preliminary investigation into a population beyond the southern extreme of its range (MSci thesis). Newcastle University, UK.

Bailey, H. \& Thompson, P.M. (2006) Quantitative analysis of bottlenose dolphin movement patterns and their relationship with foraging. Journal of Animal Ecology, 75, 456-465

Bailey, H., Corkrey, R., Cheney, B., \& Thompson, P. M. (2013). Analyzing temporally correlated 683 684 dolphin sightings data using generalized estimating equations. Marine Mammal Science, 29(1), 123-141.

685 Bates, D. M., \& Venables, W. N. (2012). Package splines version 2.15.0, R Core Team. 
686 Boyce, M. S., Vernier, P. R., Nielsen, S. E., \& Schmiegelow, F. K. (2002). Evaluating resource 687 selection functions. Ecological Modelling, 157(2), 281-300.

688 Burnham, K. P., \& Anderson, D. R. (2002). Model selection and inference: a practical information 689 theoretic approach (2nd ed.). New York: Springer.

690 Burnham, K. P., Anderson, D. R., White, G. C., Brownie, C., \& Pollock, K. H. (1987). Design and 691 analysis of fish survival experiments based on release-recapture data. American Fisheries $692 \quad$ Society Monograph 5, 1-437.

693 Callaway, R., Alsvåg, J., De Boois, I., Cotter, J., Ford, A., Hinz, H., . . Piet, G. (2002). Diversity and 694 community structure of epibenthic invertebrates and fish in the North Sea. ICES Journal of 695 Marine Science: Journal du Conseil, 59(6), 1199-1214.

696 Cañadas, A., Sagarminaga, R., De Stephanis, R., Urquiola, E., \& Hammond, P. S. (2005). Habitat 697

Cantor, M., Wedekin, L. L., Daura-Jorge, F. G., Rossi-Santos, M. R., \& Simões-Lopes, P. C. (2012). preference modelling as a conservation tool: proposals for marine protected areas for cetaceans in southern Spanish waters. Aquatic Conservation-Marine and Freshwater Ecosystems, 15(5), 495-521.

Cheney, B. (2017). Temporal variation in the demographics and dynamics of a bottlenose dolphin 704 population ( $\mathrm{PhD}$ thesis). University of Aberdeen, UK.

Cheney, B., Corkrey, R., Durban, J. W., Grellier, K., Hammond, P. S., Islas-Villanueva, V., . . . Thompson, P. M. (2014). Long-term trends in the use of a protected area by small cetaceans in relation to changes in population status. Global Ecology and Conservation, 2(0), 118-128.

708 Cheney, B., Corkrey, R., Quick, N.J., Janik, V.M., Islas-Villanueva, V., Hammond, P.S. and 709 Thompson, P.M, (2012). Site Condition Monitoring of bottlenose dolphins within the Moray Firth Special Area of Conservation: 2008-2010. Scottish Natural Heritage Commissioned Report No. 512. 
712 Cheney, B., Graham, I. M., Barton, T. R., Hammond, P. S., \& Thompson, P. M. (2018). Site

713 Conditioning Monitoring of bottlenose dolphins within the Moray Firth Special Area of

714 Conservation: 2014-2016. Scottish Natural Heritage Research Report No. 1021

715 Cheney, B., Thompson, P. M., Ingram, S. N., Hammond, P. S., Stevick, P. T., Durban, J. W., . .

716 Wilson, B. (2013). Integrating multiple data sources to assess the distribution and abundance

717 of bottlenose dolphins Tursiops truncatus in Scottish waters. Mammal Review, 43, 71-88.

718 Choquet, R., Lebreton, J.-D., Gimenez, O., Reboulet, A.-M., \& Pradel, R. (2009). U-CARE: Utilities

719 for performing goodness of fit tests and manipulating Capture-Recapture data. Ecography, 32,

$720 \quad 1071-1074$

721 Council of the European Communities (1992). Directive 92/43/EEC of the 21 May 1992 on the

722 conservation of natural habitats and of wild fauna and flora. Official Journal of the European

723 Communities (L 206/7), pp. 7-50.

724 Council of Europe (2018). https://www.coe.int/en/web/bern-convention/home. [19 November 2018]

725 Culloch, R. M., \& Robinson, K. P. (2008). Bottlenose dolphins using coastal regions adjacent to a

726 Special Area of Conservation in north-east Scotland. Journal of the Marine Biological

727 Association of the United Kingdom, 88(6), 1237-1243.

728 Curran, S., Wilson, B., \& Thompson, P. (1996). Recommendations for the suitable management of the 729 bottlenose dolphin population in the Moray Firth. Scottish Natural Heritage Review. No 56.

730 Embling, C. B., Gillibrand, P. A., Gordon, J., Shrimpton, J., Stevick, P. T., \& Hammond, P. S. (2010).

731 Using habitat models to identify suitable sites for marine protected areas for harbour

732 porpoises (Phocoena phocoena). Biological Conservation, 143(2), 267-279.

733 Ferrier, G. \& Anderson, J. M. (1997) A multi-disciplinary study of frontal systems in the Tay estuary, 734 Scotland. Estuarine, Coastal and Shelf Science, 45, 317-336

735 Fielding, A. H., \& Bell, J. F. (1997). A review of methods for the assessment of prediction errors in 736 conservation presence/absence models. Environmental conservation, 24(01), 38-49.

737 Freeman, E. A., \& Moisen, G. (2008). PresenceAbsence: An R package for presence absence analysis. $738 \quad$ Journal of Statistical Software, 23(11), 1-31. 
739 Gerrodette, T., \& Rojas-Bracho, L. (2011). Estimating the success of protected areas for the vaquita, $740 \quad$ Phocoena sinus. Marine Mammal Science, 27(2), 101-125.

741 Gormley, A. M., Slooten, E., Dawson, S. M., Barker, R. J., Rayment, W., du Fresne, S., \& Brager, S. (2012). First evidence that marine protected areas can work for marine mammals. Journal of Applied Ecology, 49(2), 474-480.

744 Halekoh, U., Højsgaard, S., \& Yan, J. (2006). The R package geepack for generalized estimating 745 equations. Journal of Statistical Software, 15(2), 1-11.

Halpern, B. S. (2003). The impact of marine reserves: do reserves work and does reserve size matter? Ecological Applications, 13(1), S117-S137.

Hammond, P. S. (2010). Estimating the abundance of marine mammals. In I. L. Boyd, W. D. Bowen, \& S. Iverson (Eds.), Marine mammal ecology and conservation: a handbook of techniques (pp. 42-67), Oxford, UK: Oxford University Press.

Hooker, S. K., \& Gerber, L. R. (2004). Marine reserves as a tool for ecosystem-based management:

Hammond, P.S., Macleod, K., Berggren, P., Borchers, D.L., Burt, L., Cañadas, A., ... Vázquez, J.A. (2013) Cetacean abundance and distribution in European Atlantic shelf waters to inform conservation and management. Biological Conservation, 164, 107-122.

Hansom, J. D., Rennie, A. F., Dunlop, A. \& Drummond J. (2011) A methodology to assess the causes and rates of change to Scotland's beaches and sand dunes Phase 1. Scottish Natural Heritage Commissioned Report No. 364

Hardin, J., \& Hilbe, J. (2003). Generalized Estimating Equations. London: Chapman \& Hall/CRC Press.

Hastie, G. D., Wilson, B., \& Thompson, P. M. (2003). Fine-scale habitat selection by coastal bottlenose dolphins: application of a new land-based video-montage technique. Canadian Journal of Zoology-Revue Canadienne De Zoologie, 81(3), 469-478.

Hastie, G. D., Wilson, B., Wilson, L. J., Parsons, K. M., \& Thompson, P. M. (2004). Functional mechanisms underlying cetacean distribution patterns: hotspots for bottlenose dolphins are linked to foraging. Marine Biology, 144(2), 397-403. the potential importance of megafauna. BioScience, 54(1), 27-39. 
767 Janik, V. (2000). Food-related bray calls in wild bottlenose dolphins (Tursiops truncatus).

768 Proceedings of the Royal Society of London. Series B: Biological Sciences, 267(1446), 923-

$969+927$

770 JNCC. (2017). http://jncc.defra.gov.uk/default.aspx?page=7059; [05 April 2017].

771 Kendall, W. L. (1999). Robustness of closed capture-recapture methods to violations of the closure $772 \quad$ assumption. Ecology, 80, 2517-2525.

773 Kendall, W. L., Nichols, J. D., \& Hines, J. E. (1997). Estimating temporary emigration using capture774 recapture data with Pollock's robust design. Ecology, 78(2), 563-578.

775 Laake, J. L. (2013). RMark: An R Interface for Analysis of Capture-Recapture Data with MARK.

$776 \quad$ AFSC Processed Rep 2013-01, 25p.

777 Lebreton, J.-D., Burnham, K. P., Clobert, J., \& Anderson, D. R. (1992). Modeling survival and testing 778 biological hypotheses using marked animals: a unified approach with case studies. Ecological $779 \quad$ Monographs, 62(1), 67-118.

780 Liang, K. Y., \& Zeger, S. L. (1986). Longitudinal data analysis using generalized linear models. $781 \quad$ Biometrika, 73, 13-22.

782 Manifold System Release 8.0. (2013). www.manifold.net.

783 Marine Mammal Protected Areas Task Force (2018)

784 https://www.marinemammalhabitat.org/activities/immas/ [05 July 2018]

785 Marine Scotland Information (2018) http://marine.gov.scot/data/aberdeen-harbour-expansion$786 \quad$ appropriate-assessment [21 November 2018]

787 Marine Scotland Science. (2012). Salmon and Sea Trout catches summary data 2012.

788 http://www.scotland.gov.uk/Topics/marine/science/Publications/stats/SalmonSeaTroutCatche 789 s/2012Final/SummaryData

790 Marley, S., Cheney, B. \& Thompson, P.M. (2013) Using tooth rakes to monitor population and sex 791 differences in aggressive behaviour in bottlenose dolphins (Tursiops truncatus). Aquatic $792 \quad$ Mammals, 39, 107-115. 
793 Mendes, S., Turrell, W., Lutkebohle, T., \& Thompson, P. (2002). Influence of the tidal cycle and a tidal intrusion front on the spatio-temporal distribution of coastal bottlenose dolphins. Marine Ecology-Progress Series, 239, 221-229.

Mills, D. (1986). The biology of Scottish salmon. In Jenkins, D \& Shearer, V.M. (Eds.), The Status of 797 Atlantic Salmon in Scotland (pp 10-19), Huntingdon, UK: Institute of Terrestrial Ecology, Natural Environmental Research Council.

Mudge, G., Crooke, C., \& Barrett, C. (1984). The offshore distribution and abundance of seabirds in the Moray Firth. Unpublished report to Britoil, RSPB, Munlochy

Pan, W. (2001). Akaike's information criterion in generalized estimating equations. Biometrics, 57(1), 120-125.

Pearce, J., \& Ferrier, S. (2000). Evaluating the predictive performance of habitat models developed using logistic regression. Ecological Modelling, 133(3), 225-245.

Pirotta, E., Matthiopoulos, J., MacKenzie, M., Scott-Hayward, L., \& Rendell, L. (2011). Modelling sperm whale habitat preference: a novel approach combining transect and follow data. Marine Ecology Progress Series, 436, 257-272.

Pirotta, E., Thompson, P. M., Miller, P. I., Brookes, K. L., Cheney, B., Barton, T. R., . . Lusseau, D. (2014). Scale-dependent foraging ecology of a marine top predator modelled using passive acoustic data. Functional Ecology, 28(1), 206-217.

Pledger, S. (2000). Unified maximum likelihood estimates for closed capture-recapture models using mixtures. Biometrics, 56, 434-442.

Pledger, S. \& Phillpot, P. (2008) Using Mixtures to Model Heterogeneity in Ecological CaptureRecapture Studies. Biometrical Journal, 50, 1022-1034.

817 Pollock, K. H., Nichols, J. D., Brownie, C., \& Hines, J. E. (1990). Statistical inference for capturerecapture experiments. Wildlife Monographs 107, 3-97. 
819 Praca, E., Gannier, A., Das, K., \& Laran, S. (2009). Modelling the habitat suitability of cetaceans: 820 example of the sperm whale in the northwestern Mediterranean Sea. Deep Sea Research Part 821 I: Oceanographic Research Papers, 56(4), 648-657.

822 Quick, N. J. (2006). Vocal behaviour and abundance of bottlenose dolphins in St Andrews Bay, $823 \quad$ Scotland (PhD thesis). University of St Andrews, UK.

824 Quick, N. J., Arso, M., Cheney, B., Islas-Villanueva, V., Janik, V. M., Thompson, P. M., \& 825 Hammond, P. S. (2014). The east coast of Scotland bottlenose dolphin population: improving 826 understanding of ecology outside the Moray Firth SAC. Report to DECC under offshore 827 energy SEA programme. Document identifier URN: 14D/086

828 R Core Team. (2016). R: A language and environment for statistical computing. R Foundation for 829 Statistical Computing. R Foundation for Statistical Computing, Vienna, Austria. $830 \quad$ http://www.R-project.org/

831 Rayment, W., Dawson, S., \& Slooten, E. (2010). Seasonal changes in distribution of Hector's dolphin 832 at Banks Peninsula, New Zealand: implications for protected area design. Aquatic 833 Conservation: Marine and Freshwater Ecosystems, 20(1), 106-116.

834 Reeves, R. R. (2000). The value of sanctuaries, parks, and reserves (protected areas) as tools for 835 conserving marine mammals. Final Report to the Marine Mammal Commission, contract 836 number T74465385. Marine Mammal Commission, Bethesda, MD. 50 pp.

837 Santos, M., Pierce, G., Reid, R., Patterson, I., Ross, H., \& Mente, E. (2001). Stomach contents of 838 bottlenose dolphins (Tursiops truncatus) in Scottish waters. Journal of the Marine Biological 839 Association of the UK, 81(05), 873-878.

840 Scottish Government (2014).

841 https://www2.gov.scot/Topics/marine/Licensing/marine/scoping/Seagreen3/seagreenaa [21 $842 \quad$ November 2018]

843 Scottish Government (2016). http://www.gov.scot/Topics/marine/marine844 environment/mpanetwork/harbourporpoisesacs [29 September 2016]. 845 Scottish Government (2017). http://www.gov.scot/Topics/marine/marine-environment/mpanetwork [5 $846 \quad$ July 2018] 
847 Scottish Government. (2018). http://www.gov.scot/Topics/marine/Licensing/marine/scoping [6 June 2018].

849 Sea Watch Foundation. (2018). http://www.seawatchfoundation.org.uk/7-north-east-england/ [19 May 2018]

851 Sharples, R. J., Arrizabalaga, B., \& Hammond, P. S. (2009). Seals, sandeels and salmon: diet of 852 harbour seals in St. Andrews Bay and the Tay Estuary, southeast Scotland. Marine Ecology Progress Series, 390, 265-276.

Silva, M. A., Prieto, R., Magalhães, S., Seabra, M. I., Machete, M., \& Hammond, P. S. (2012). Incorporating information on bottlenose dolphin distribution into marine protected area design. Aquatic Conservation: Marine and Freshwater Ecosystems, 22, 122-133.

Sing, T., Sander, O., Beerenwinkel, N., \& Lengauer, T. (2005). ROCR: visualizing classifier performance in R. Bioinformatics, 21(20), 3940-3941.

SiteLink Scottish Natural Heritage (2018) https://sitelink.nature.scot/site/8327 [21 November 2018]

Smith, H. C., Pollock, K., Waples, K., Bradley, S., \& Bejder, L. (2013). Use of the robust design to estimate seasonal abundance and demographic parameters of a coastal bottlenose dolphin (Tursiops aduncus) population. PLoS ONE, 8(10), e76574. doi:10.1371/journal.pone.0076574

SNH Natura Casework Guidance (2018) Version 9.0 https://www.nature.scot/natura-caseworkguidance-how-consider-plans-and-projects-affecting-special-areas-conservation-sacs [5 November 2018]

Sveegaard, S., Teilmann, J., Tougaard, J., Dietz, R., Mouritsen, K.N., Desportes, G. \& Siebert, U.

873 Swets, J. A. (1988). Measuring the accuracy of diagnostic systems. Science, 240(4857), 1285-1293. 
874 Taylor, B. L., Chivers, S. J., Larese, J \& Perrin, W. F. (2007). Generation length and percent mature

Thompson, P. M., Cheney, B., Ingram, S., Stevick, P. T., Wilson, B., \& Hammond, P. S. (2011). Distribution, abundance and population structure of bottlenose dolphins in Scottish waters. Scottish Natural Heritage Report No. 354

880 Verborgh, P., de Stephanis, R., Perez, S., Jaget, Y., Barbraud, C., \& Guinet, C. (2009). Survival rate, 881 abundance, and residency of long-finned pilot whales in the Strait of Gibraltar. Marine Mammal Science, 25(3), 523-536.

Weir, C. R., Canning, S., Hepworth, K., Sim, I., \& Stockin, K. A. (2008). A long-term opportunistic photo-identification study of bottlenose dolphins (Tursiops truncatus) off Aberdeen, United Kingdom: conservation value and limitations. Aquatic Mammals, 34(4), 436-447.

White, G. C., \& Burnham, K. P. (1999). Program MARK: survival estimation from populations of marked animals. Bird Study, 46, 120-139.

Williams, R., Lusseau, D., \& Hammond, P. S. (2009). The role of social aggregations and protected areas in killer whale conservation: The mixed blessing of critical habitat. Biological Conservation, 142, 709-719.

Wilson, B. (2016). Might marine protected areas for mobile megafauna suit their proponents more than the animals? Aquatic Conservation: Marine and Freshwater Ecosystems, 26(1), 3-8.

Wilson, B., Hammond, P. S., \& Thompson, P. M. (1999). Estimating size and assessing trends in a coastal bottlenose dolphin population. Ecological Applications, 9(1), 288-300.

Wilson, B., Reid, R. J., Grellier, K., Thompson, P. M., \& Hammond, P. S. (2004). Considering the temporal when managing the spatial: a population range expansion impacts protected areasbased management for bottlenose dolphins. Animal Conservation, 7(4), 331-338.

Wilson, B., Thompson, P. M., \& Hammond, P. S. (1997). Habitat use by bottlenose dolphins: seasonal distribution and stratified movement patterns in the Moray Firth, Scotland. Journal of Applied Ecology, 34(6), 1365-1374.

Wood, S. (2006). Generalized additive models: an introduction with R. CRC press. 
902 Würsig, B., \& Jefferson, T. A. (1990). Methods for photo-identification for small cetaceans. Reports 903 to the International Whaling Comission (Special Issue Number 12), 43-51.

904 Zuur, A. F., Ieno, E. N., Walker, N. J., Saveliev, A. A., \& Smith, G. M. (2009). Mixed Effects Models 905 and Extentions in Ecology with R. New York: Springer-Verlag, 574 pp.

906 Zweig, M. H., \& Campbell, G. (1993). Receiver-operating characteristic (ROC) plots: a fundamental 907 evaluation tool in clinical medicine. Clinical chemistry, 39(4), 561-577. 


\section{Tables}

Table 1. Photo-identification survey effort conducted between 2009 and 2015 in the overall study area (top) and in St Andrews Bay and the Tay estuary (bottom, also included in the overall effort). Details on survey effort dates, number of secondary sampling occasions (i.e. calendar months), number of surveys and encounters, and number of marked animals (total and new) identified from good quality photographs in each year are shown. The overall study area includes the Moray Firth SAC and St Andrews Bay and the Tay estuary (both surveyed annually), the outer Moray Firth (surveyed more occasionally), and the Firth of Forth and Montrose to Aberdeen area (both only surveyed in 2012 and 2013). Note that this difference in survey area accounts for the higher number of marked animals in certain years compared to Table 2 .

\begin{tabular}{|c|c|c|c|c|c|c|}
\hline Year & Effort & $\begin{array}{c}\text { Secondary } \\
\text { occasions }\end{array}$ & $\begin{array}{c}\text { No. } \\
\text { Surveys }\end{array}$ & $\begin{array}{c}\text { No. } \\
\text { Encounters }\end{array}$ & $\begin{array}{c}\text { Marked } \\
\text { animals }\end{array}$ & $\begin{array}{c}\text { New } \\
\text { animals }\end{array}$ \\
\hline \multicolumn{5}{|l|}{ Overall study area } \\
\hline 2009 & 06 May-30 Sep & 5 & 42 & 137 & 89 & - \\
\hline 2010 & 05 May-21 Sep & 5 & 32 & 160 & 92 & 8 \\
\hline 2011 & 03 May-29 Sep & 5 & 31 & 145 & 89 & 3 \\
\hline 2012 & 02 May-27 Sep & 5 & 41 & 172 & 102 & 9 \\
\hline 2013 & 02 May-27 Sep & 5 & 50 & 218 & 103 & 7 \\
\hline 2014 & 02 May-22 Sep & 5 & 29 & 161 & 85 & 7 \\
\hline 2015 & 08 May-30 Sep & 5 & 29 & 146 & 99 & 5 \\
\hline St Andrews Bay and the Tay estuary & & & & \\
\hline 2009 & 15 Jun-24 Aug & 3 & 7 & 30 & 43 & - \\
\hline 2010 & 17 Jun-1 Sep & 4 & 8 & 39 & 42 & 9 \\
\hline 2011 & 6 Jun-31 Aug & 3 & 10 & 38 & 42 & 4 \\
\hline 2012 & 9 May-27 Sep & 5 & 17 & 48 & 42 & 6 \\
\hline 2013 & 7 May-27 Sep & 5 & 20 & 70 & 43 & 6 \\
\hline 2014 & 13 May-9 Sep & 4 & 8 & 26 & 33 & 7 \\
\hline 2015 & 23 May-30 Sep & 4 & 9 & 24 & 52 & 7 \\
\hline
\end{tabular}


Table 2. Number of marked animals identified in the sub-areas of St Andrews Bay and the Tay estuary, and/or in the Moray Firth SAC between 2009 and 2015. Annual proportions of the total number of marked animals seen only in each of the two sub-areas or in both sub-areas are given next to the number of marked animals seen.

\begin{tabular}{|c|c|c|c|c|c|c|}
\hline Year & $\begin{array}{c}\text { Number of } \\
\text { marked } \\
\text { animals }\end{array}$ & $\begin{array}{c}\text { St Andrews } \\
\text { Bay and } \\
\text { Tay estuary }\end{array}$ & $\begin{array}{c}\text { Moray } \\
\text { Firth } \\
\text { SAC }\end{array}$ & $\begin{array}{c}\text { St Andrews } \\
\text { Bay and the } \\
\text { Tay estuary } \\
\text { only }\end{array}$ & $\begin{array}{c}\text { Moray } \\
\text { Firth } \\
\text { SAConly }\end{array}$ & $\begin{array}{c}\text { Both } \\
\text { areas }\end{array}$ \\
\hline 2009 & 89 & 43 & 53 & $36(40.4 \%)$ & $46(51.7 \%)$ & $7(7.9 \%)$ \\
\hline 2010 & 92 & 42 & 60 & $32(34.8 \%)$ & $50(54.3 \%)$ & $10(10.9 \%)$ \\
\hline 2011 & 87 & 42 & 52 & $35(40.2 \%)$ & $45(51.7 \%)$ & $7(8.0 \%)$ \\
\hline 2012 & 98 & 42 & 59 & $39(39.8 \%)$ & $56(57.1 \%)$ & $3(3.1 \%)$ \\
\hline 2013 & 91 & 43 & 51 & $40(44.0 \%)$ & $48(52.7 \%)$ & $3(3.0 \%)$ \\
\hline 2014 & 74 & 33 & 41 & $33(44.6 \%)$ & $41(55.4 \%)$ & $0(0 \%)$ \\
\hline 2015 & 99 & 52 & 53 & $46(46.5 \%)$ & $47(47.5 \%)$ & $6(6.1 \%)$ \\
\hline 2009 to 2015 & 128 & 82 & 83 & $45(35.2 \%)$ & $46(35.9 \%)$ & $37(28.9 \%)$ \\
\hline
\end{tabular}


Table 3. Model selection for the robust design models to estimate the abundance of marked animals in the overall study area (top) and in St Andrews Bay and the Tay estuary (bottom). Parameters estimated: survival probability $(\phi)$, capture probabilities $(\mathrm{p})$, temporary emigration probabilities $(\mathrm{\gamma})$, and Pledger's mixture parameter for two types $(\pi)$. In the model description: $()=$. constant; $(\mathrm{t})=$ time-specific for primary sampling occasions; (txs) $=$ timespecific for primary $(\mathrm{t})$ and secondary $(\mathrm{s})$ sampling occasions; for temporary emigration $\gamma^{\prime \prime}=\gamma^{\prime}=0=$ no emigration; $\mathrm{y}^{\prime \prime}(\mathrm{x})=\mathrm{y}^{\prime}(\mathrm{x})=$ random emigration; $\mathrm{y}^{\prime \prime}(\mathrm{x}) \mathrm{y}^{\prime}(\mathrm{x})=$ Markovian emigration. Models are ordered from smallest to largest AICc.

Models not incorporating heterogeneity $(\pi)$ did not receive support in the overall study area dataset and are not shown. Only the top 13 models are shown for the St Andrews Bay and the Tay estuary dataset (the others received less support)

\begin{tabular}{|c|c|c|c|c|c|c|}
\hline $\begin{array}{l}\text { Model } \\
\text { no. }\end{array}$ & Model & $\begin{array}{c}\text { No. } \\
\text { parameters }\end{array}$ & $\mathrm{AICc}$ & $\Delta \mathrm{AICc}$ & $\begin{array}{c}\mathrm{AIC}_{\mathrm{c}} \\
\text { weight }\end{array}$ & Deviance \\
\hline \multicolumn{7}{|c|}{ Overall study area } \\
\hline 1 & $\phi_{(.)} \gamma^{\prime \prime}(\mathrm{t})=\gamma_{(\mathrm{t})}^{\prime} \mathrm{p}_{(\mathrm{txs})} \pi_{(\mathrm{t})}$ & 57 & -437.22 & 0.00 & 0.792 & 2932 \\
\hline 2 & $\phi_{(.)} \gamma^{\prime \prime}=\gamma^{\prime}=0 \mathrm{p}_{(\mathrm{txs})} \pi_{(\mathrm{t})}$ & 52 & -434.51 & 2.71 & 0.204 & 2946 \\
\hline 3 & $\phi_{(.)} \gamma^{\prime \prime}=\gamma^{\prime}=0 p_{(\mathrm{txs})} \pi_{(.)}$ & 46 & -426.64 & 10.57 & 0.004 & 2966 \\
\hline 4 & $\phi_{(.)} \gamma_{(\mathrm{t})}^{\prime \prime} \gamma_{(.)}^{\prime} \mathrm{p}_{(\mathrm{txs})} \pi_{(\mathrm{t})}$ & 58 & -409.02 & 28.20 & 0.000 & 2958 \\
\hline 5 & $\phi_{(.)} \gamma^{\prime \prime}{ }_{(.)}=\gamma_{(.)}^{\prime} p_{(t x s)} \pi_{(t)}$ & 53 & -408.85 & 28.36 & 0.000 & 2969 \\
\hline 6 & $\phi_{(.)} \gamma^{\prime \prime}{ }_{(t)}=\gamma_{(t)}^{\prime} p_{(t x s)} \pi_{(t)}$ & 54 & -405.00 & 32.22 & 0.000 & 2971 \\
\hline 7 & $\phi_{(.)} \gamma_{(.)}^{\prime \prime} \gamma_{(\mathrm{t})}^{\prime} \mathrm{p}_{(\mathrm{txs})} \pi_{(\mathrm{t})}$ & 58 & -402.60 & 34.62 & 0.000 & 2965 \\
\hline 8 & $\phi_{(.)} \gamma_{(\mathrm{t})}^{\prime \prime} \gamma_{(\mathrm{t})}^{\prime} \mathrm{p}_{(\mathrm{txs})} \pi_{(\mathrm{t})}$ & 62 & -401.22 & 36.00 & 0.000 & 2958 \\
\hline \multicolumn{7}{|c|}{ St Andrews Bay and the Tay estuary } \\
\hline 9 & $\phi_{(.)} \gamma^{\prime \prime}{ }_{(.)}=\gamma_{(.)}^{\prime} p_{(\mathrm{txs})} \pi_{(\mathrm{t})}$ & 46 & 87.77 & 0.00 & 0.524 & 992 \\
\hline 10 & $\phi_{(.)} \gamma_{(.)}^{\prime \prime} \gamma_{(.)}^{\prime} p_{(t x s)} \pi_{(t)}$ & 47 & 89.83 & 2.06 & 0.187 & 992 \\
\hline 11 & $\phi_{(.)} \gamma_{(.)}^{\prime \prime} \gamma_{(.)}^{\prime} p_{(\mathrm{txs})}$ & 38 & 90.66 & 2.89 & 0.124 & 1014 \\
\hline 12 & $\phi_{(.)} \gamma^{\prime \prime}=\gamma^{\prime}=0 \mathrm{p}_{(\mathrm{txs})} \pi_{(\mathrm{t})}$ & 45 & 90.77 & 3.00 & 0.117 & 998 \\
\hline 13 & $\phi_{(.)} \gamma^{\prime \prime}{ }_{(t)}=\gamma_{(t)}^{\prime} p_{(t x s)} \pi_{(t)}$ & 50 & 94.87 & 7.10 & 0.015 & 990 \\
\hline 14 & $\phi_{(.)} \gamma^{\prime \prime}(\mathrm{t}) \gamma_{(.)}^{\prime} \mathrm{p}_{(\mathrm{txs})} \pi_{(\mathrm{t})}$ & 51 & 95.79 & 8.02 & 0.009 & 989 \\
\hline 15 & $\phi_{(.)} \gamma^{\prime \prime}{ }_{(\mathrm{t})}=\gamma^{\prime}{ }_{(\mathrm{t})} \mathrm{p}_{(\mathrm{txs})}$ & 41 & 96.06 & 8.29 & 0.008 & 1012 \\
\hline 16 & $\phi_{(.)} \gamma^{\prime \prime(t)} \gamma_{(.)}^{\prime} p_{(t x s)}$ & 42 & 97.28 & 9.51 & 0.005 & 1011 \\
\hline 17 & $\phi_{(.)} \gamma_{(.)}^{\prime \prime} \gamma_{(\mathrm{t})}^{\prime} \mathrm{p}_{(\mathrm{txs})} \pi_{(\mathrm{t})}$ & 51 & 97.33 & 9.56 & 0.004 & 990 \\
\hline 18 & $\phi_{(.)} \gamma_{(.)}^{\prime \prime} \gamma_{(t)}^{\prime} p_{(t x s)}$ & 42 & 97.39 & 9.62 & 0.004 & 1011 \\
\hline 19 & $\phi_{(.)} \gamma^{\prime \prime}=\gamma^{\prime}=0 p_{(\mathrm{txs})} \pi_{(.)}$ & 39 & 99.01 & 11.24 & 0.002 & 1020 \\
\hline 20 & $\phi_{(.)} \gamma^{\prime \prime}{ }_{(t)} \gamma_{(t)}^{\prime} p_{(t x s)} \pi_{(t)}$ & 55 & 102.59 & 14.82 & 0.000 & 986 \\
\hline 21 & $\phi_{(.)} \gamma^{\prime \prime}{ }_{(t)} \gamma_{(t)}^{\prime} p_{(t x s)}$ & 46 & 103.43 & 15.66 & 0.000 & 1008 \\
\hline
\end{tabular}


Table 4. Annual estimates of abundance of animals using the overall study area (top) and St Andrews Bay and the Tay estuary (bottom) with associated precision. $\theta=$ proportion of marked animals; $\hat{N}=$ abundance of marked animals; $\hat{N}_{\text {total }}=$ total abundance of animals; percentage $=$ percentage of the total estimated population using St Andrews Bay.

\begin{tabular}{|c|c|c|c|c|c|c|}
\hline Year & $\hat{\mathbf{N}}$ & $\mathbf{C V}(\hat{\mathbf{N}})$ & $\hat{\boldsymbol{\theta}}$ & $\mathbf{C V}(\hat{\boldsymbol{\theta}})$ & $\begin{array}{c}\hat{\mathbf{N}}_{\text {total }} \\
(\mathbf{9 5 \%} \mathbf{C I})\end{array}$ & $\begin{array}{c}\mathbf{C V} \\
\left(\hat{\mathbf{N}}_{\text {total }}\right)\end{array}$ \\
\hline 2009 & 91 & 0.019 & 0.55 & 0.023 & $165(156-175)$ & 0.030 \\
\hline 2010 & 92 & 0.000 & 0.53 & 0.024 & $175(167-183)$ & 0.024 \\
\hline 2011 & 91 & 0.019 & 0.53 & 0.026 & $171(161-182)$ & 0.032 \\
\hline 2012 & 102 & 0.011 & 0.49 & 0.028 & $208(196-220)$ & 0.030 \\
\hline 2013 & 104 & 0.011 & 0.53 & 0.025 & $194(184-205)$ & 0.028 \\
\hline 2014 & 103 & 0.069 & 0.51 & 0.031 & $202(175-233)$ & 0.076 \\
\hline 2015 & 107 & 0.040 & 0.51 & 0.030 & $209(189-230)$ & 0.051 \\
\hline
\end{tabular}

\begin{tabular}{|c|c|c|c|c|c|c|c|}
\hline \multicolumn{7}{|c|}{ St Andrews Bay and the Tay estuary } & \multirow{2}{*}{$\begin{array}{c}\text { Percentage } \\
55.18 \%\end{array}$} \\
\hline 2009 & 47 & 0.063 & 0.52 & 0.051 & $91(78-106)$ & 0.081 & \\
\hline 2010 & 42 & 0.000 & 0.47 & 0.050 & $89(81-98)$ & 0.050 & $50.66 \%$ \\
\hline 2011 & 42 & 0.000 & 0.50 & 0.049 & $85(77-93)$ & 0.049 & $49.45 \%$ \\
\hline 2012 & 47 & 0.082 & 0.49 & 0.047 & $95(80-114)$ & 0.095 & $45.80 \%$ \\
\hline 2013 & 48 & 0.110 & 0.48 & 0.058 & $100(80-126)$ & 0.124 & $51.72 \%$ \\
\hline 2014 & 56 & 0.181 & 0.47 & 0.087 & 121 (84-173) & 0.201 & $59.92 \%$ \\
\hline 2015 & 59 & 0.069 & 0.52 & 0.068 & 114 (95-137) & 0.097 & $54.76 \%$ \\
\hline
\end{tabular}

Table 5. Summary of survey effort, photo-ID follows and number of encounters in 2012 and 2013 in St Andrews Bay and the Tay estuary.

\begin{tabular}{|c|c|c|c|c|c|c|}
\hline & \multicolumn{3}{|c|}{2012} & \multicolumn{3}{c|}{2013} \\
\hline Month & $\begin{array}{c}\text { On-effort } \\
(\mathrm{km})\end{array}$ & $\begin{array}{c}\text { Follow } \\
(\mathrm{km})\end{array}$ & $\begin{array}{c}\text { No. } \\
\text { Encounters }\end{array}$ & $\begin{array}{c}\text { On-effort } \\
(\mathrm{km})\end{array}$ & $\begin{array}{c}\text { Follow } \\
(\mathrm{km})\end{array}$ & $\begin{array}{c}\text { No. } \\
\text { Encounters }\end{array}$ \\
\hline May & 376 & 34 & 6 & 414 & 37 & 10 \\
\hline June & 358 & 20 & 5 & 602 & 45 & 17 \\
\hline July & 628 & 90 & 21 & 402 & 25 & 13 \\
\hline August & 225 & 15 & 5 & 243 & 16 & 18 \\
\hline September & 214 & 30 & 7 & 320 & 13 & 26 \\
\hline Total & 1801 & 189 & 44 & 1981 & 136 & 84 \\
\hline & \multicolumn{7}{|c|}{ Total 2012/13 } & 3782 & 325 & 128 \\
\hline
\end{tabular}




\section{Figure Legends}

Figure 1. Overall sampling area along the east coast of Scotland between the Moray Firth and the Firth of Forth, covering the current population's main distributional range, including the sub-areas of St Andrews Bay and the Tay estuary (dashed box), and the Moray Firth SAC. Survey effort conducted from 2009 to 2015 is shown (grey lines) with locations of bottlenose dolphin encounters (black dots).

Figure 2. Proportion of marked dolphins seen only in St Andrews and the Tay Esturay (black), only in the Moray Firth SAC (dark grey), or seen in both areas (light grey) every year (May to September) and overall between 2009 and 2015.

Figure 3. Partial residual plots of the relationship between presence of bottlenose dolphins (on the link scale) and the retained covariates (a) distance to the Tay (meters), (b) current direction (0-360 degrees), (c) current speed $(\mathrm{m} / \mathrm{s}),(\mathrm{d})$ month, $(\mathrm{e})$ sea surface temperature $\left({ }^{\circ} \mathrm{C}\right)$ and $(\mathrm{f})$ year. The shaded areas are the GEE-based $95 \%$ confidence intervals and a rug plot with the actual data values is shown at the bottom of each plot.

Figure 4. Prediction maps of probability of presence of bottlenose dolphins for different current directions (10-60 degrees, 60-220 degrees, 220-300 degrees and 300-10 degrees), with associated bottlenose dolphin presence points recorded during follows in each corresponding tidal condition.

Figure 5. Prediction maps of probability of presence of bottlenose dolphins for low $\left(0-0.15 \mathrm{~ms}^{-1}\right)$, intermediate $\left(0.15-0.5 \mathrm{~ms}^{-1}\right)$ and high $\left(>0.5 \mathrm{~ms}^{-1}\right)$ current speeds, with associated bottlenose dolphin presence points recorded during follows in each corresponding tidal condition. Note that high current speeds $\left(>0.5 \mathrm{~ms}^{-1}\right)$ did not occur in the entire surveyed area, compared to low or intermediate current speeds. 


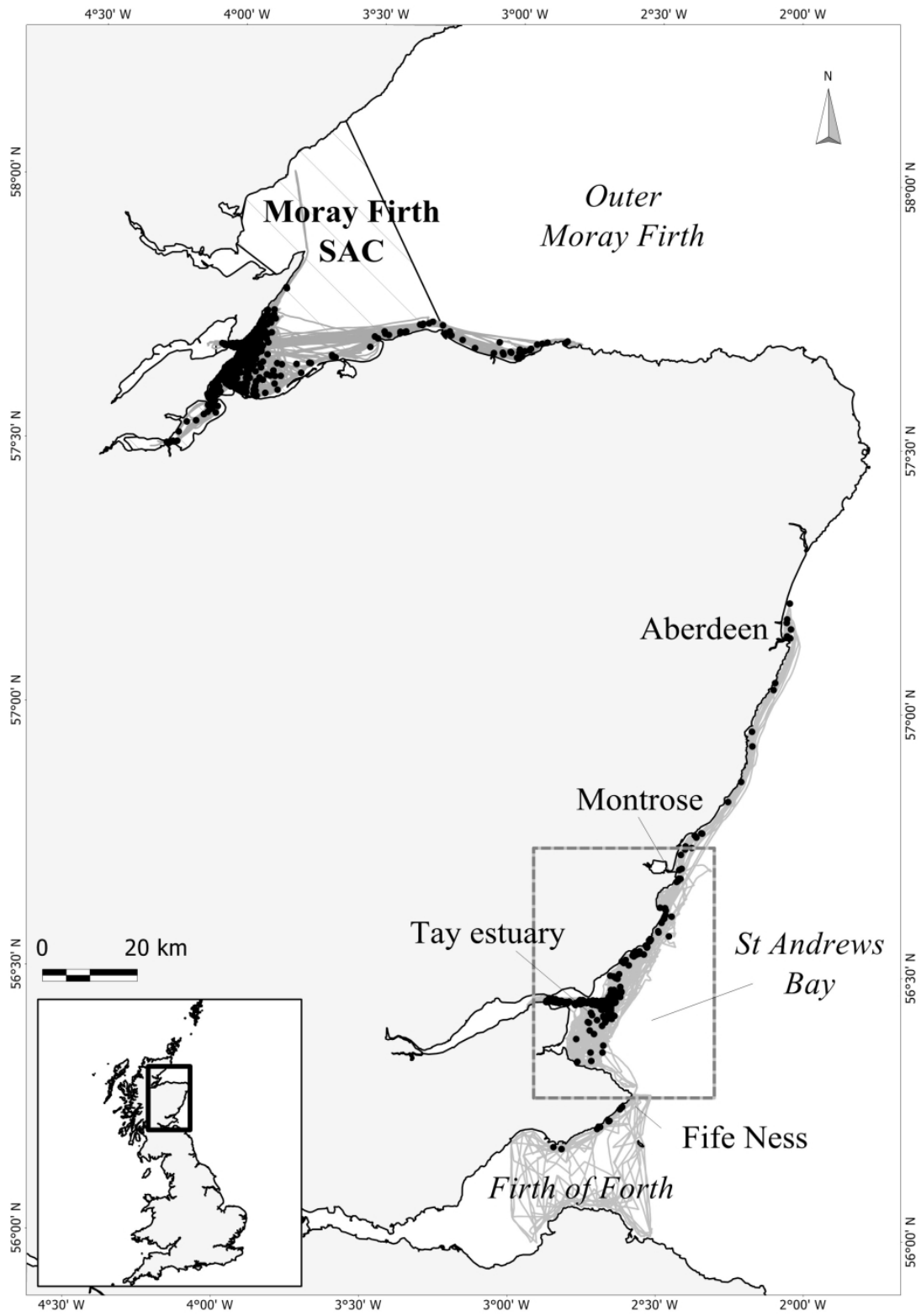

Overall sampling area along the east coast of Scotland between the Moray Firth and the Firth of Forth, covering the population's main distributional range, including the sub-areas of St Andrews Bay and the Tay estuary (dashed box), and the Moray Firth SAC. Survey effort conducted from 2009 to 2015 is shown (grey lines) with locations of bottlenose dolphin encounters (black dots).

$201 \times 288 \mathrm{~mm}(300 \times 300 \mathrm{DPI})$ 


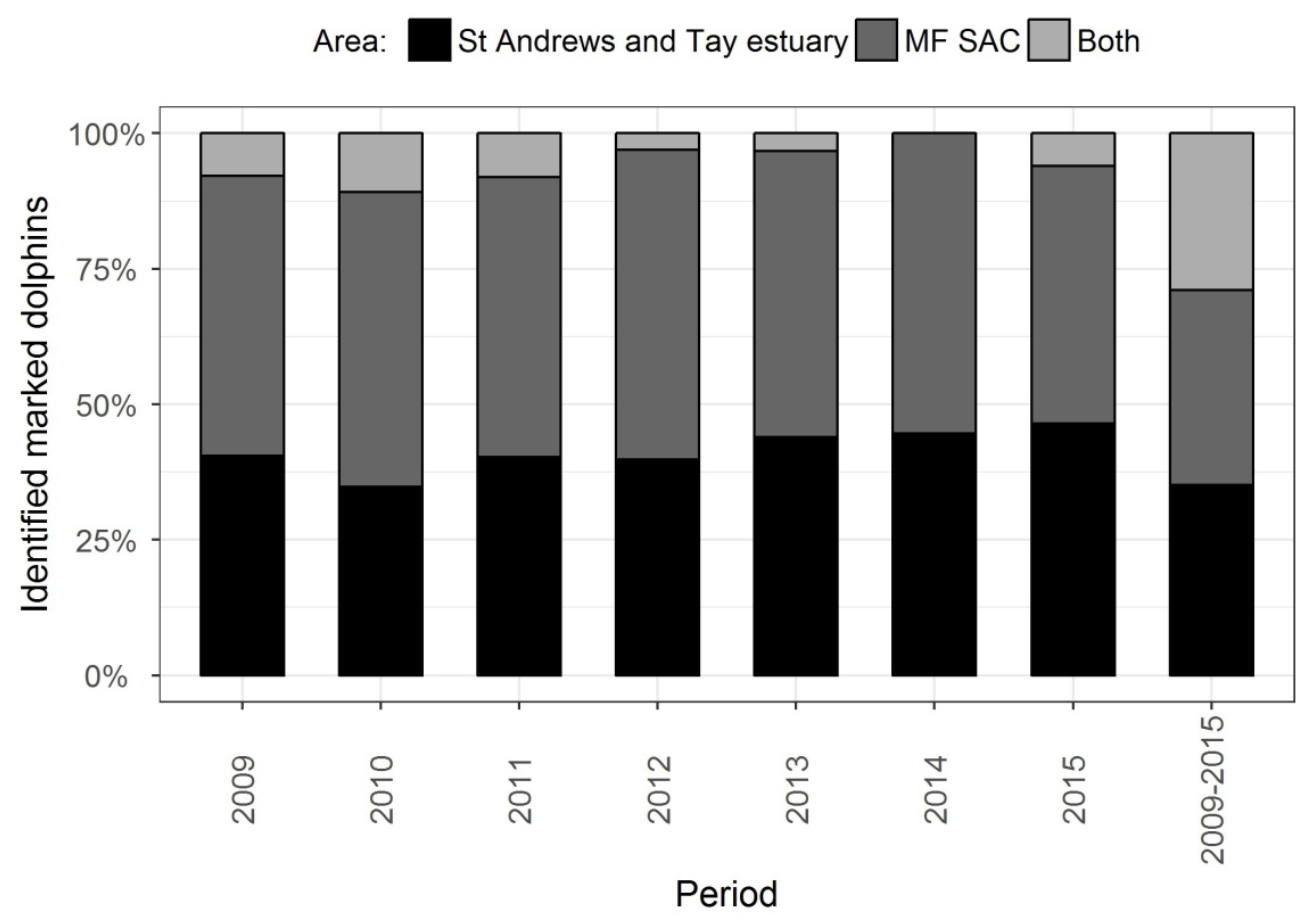

Proportion of marked dolphins seen only in St Andrews and the Tay Esturay (black), only in the Moray Firth SAC (dark grey), or seen in both areas (light grey) every year (May to September) and overall between 2009 and 2015.

$177 \times 127 \mathrm{~mm}(300 \times 300 \mathrm{DPI})$ 
a

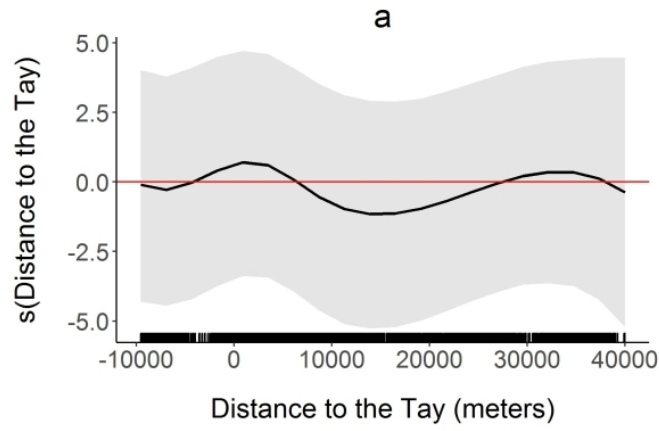

C

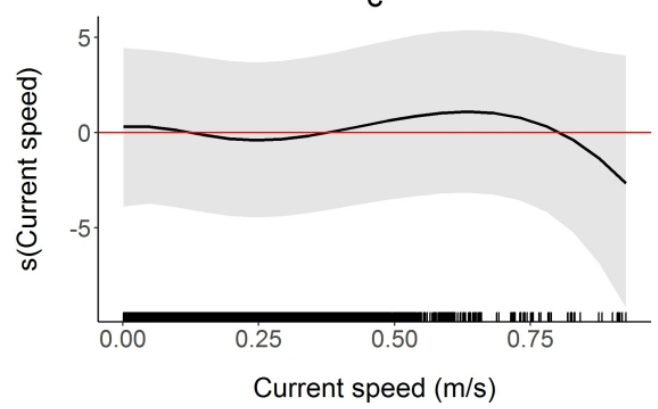

e

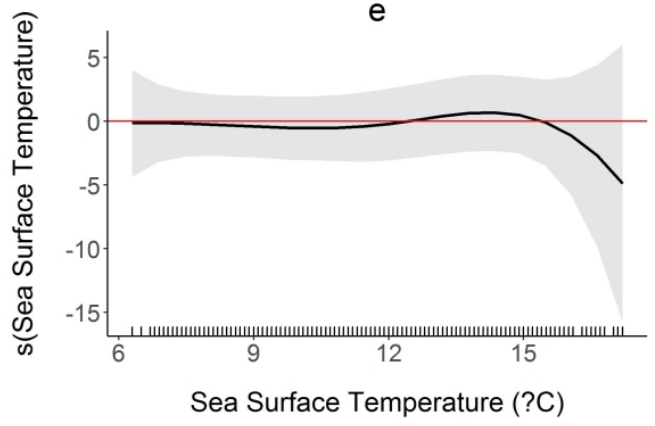

b

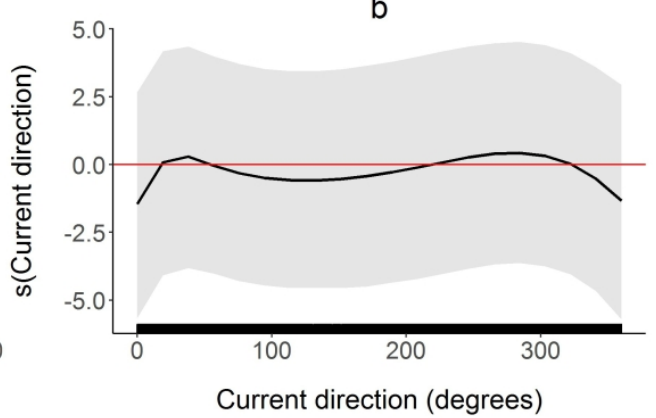

d

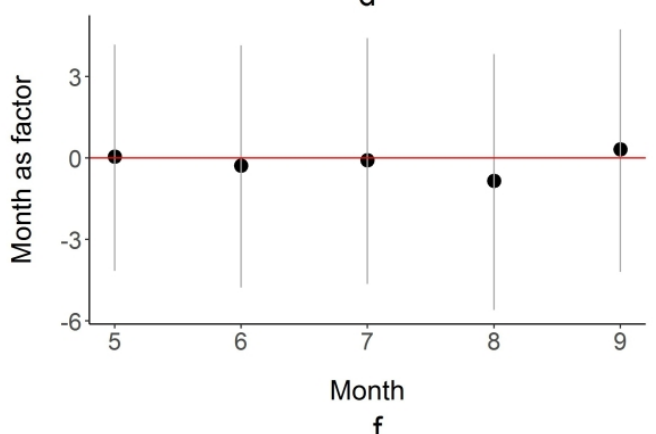

$f$

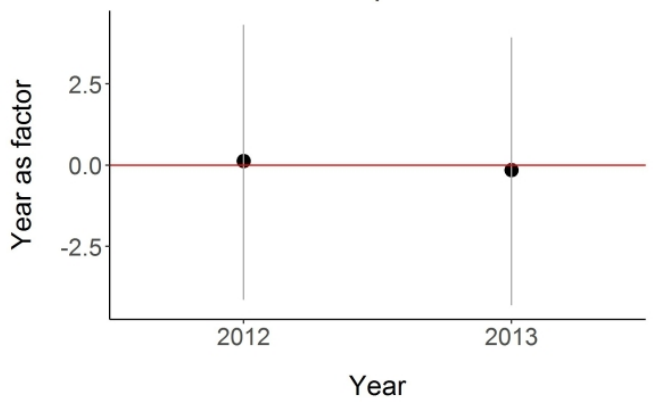

Partial residual plots of the relationship between presence of bottlenose dolphins (on the link scale) and the retained covariates (a) distance to the Tay (meters), (b) current direction (0-360 degrees), (c) current speed (m/s), (d) month, (e) sea surface temperature $\left({ }^{\circ} \mathrm{C}\right)$ and (f) year. The shaded areas are the GEEbased $95 \%$ confidence intervals and a rug plot with the actual data values is shown at the bottom of each plot.

$304 \times 304 \mathrm{~mm}(300 \times 300$ DPI $)$ 


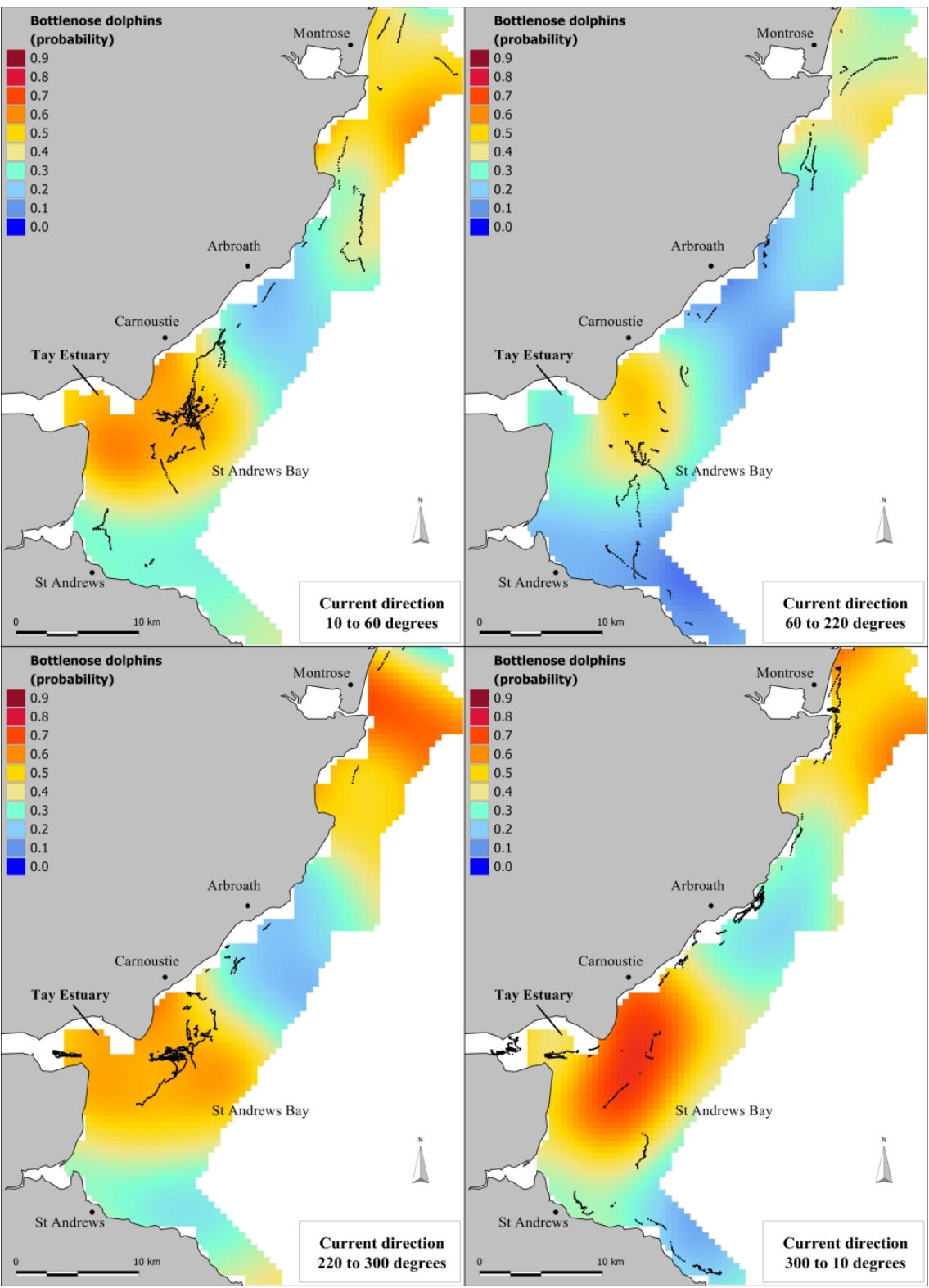

Prediction maps of probability of presence of bottlenose dolphins for different current directions (10-60 degrees, 60-220 degrees, 220-300 degrees and 300-10 degrees), with associated bottlenose dolphin presence points recorded during follows in each corresponding tidal condition.

$$
848 \times 1170 \mathrm{~mm}(72 \times 72 \mathrm{DPI})
$$




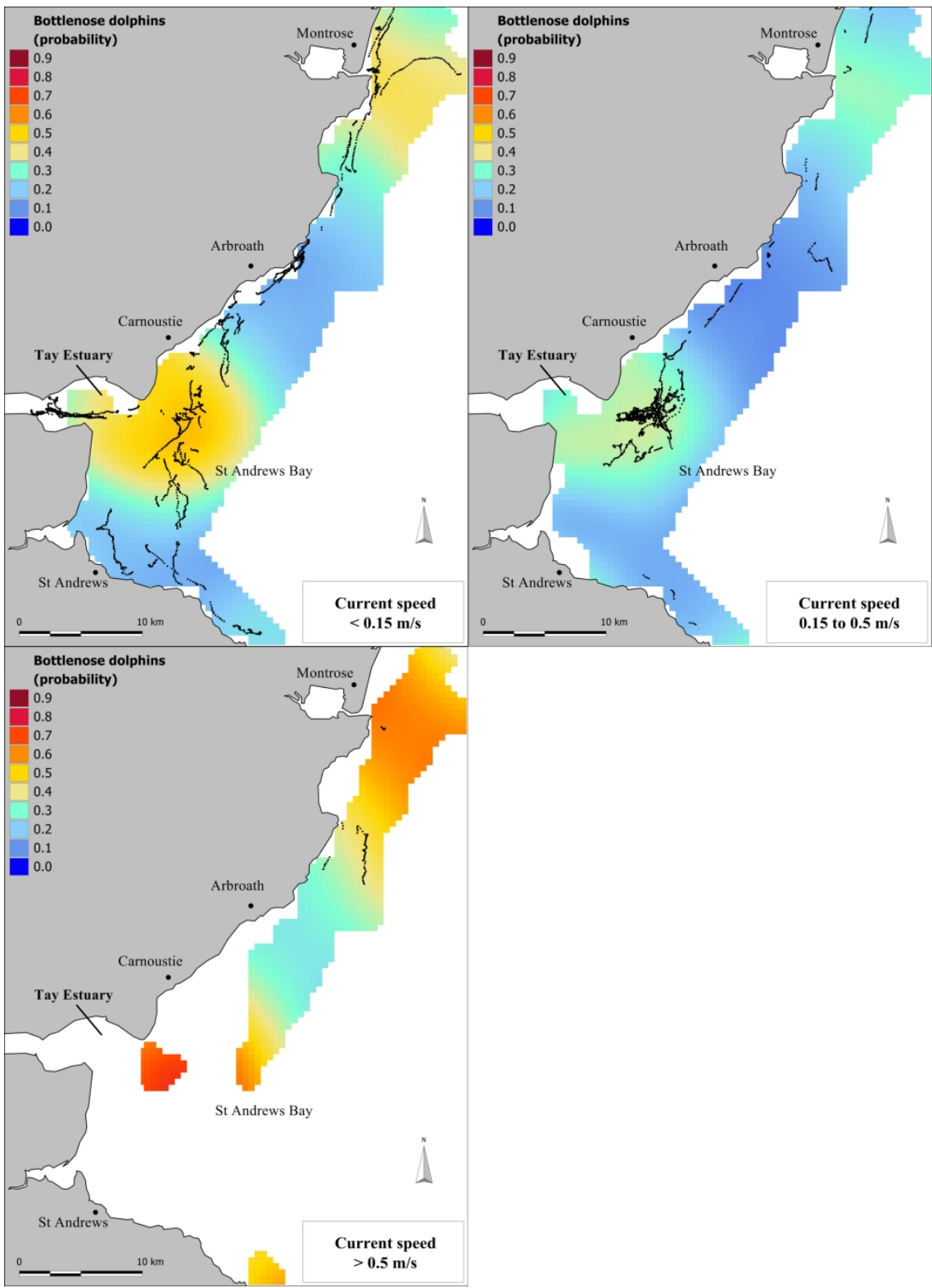

Prediction maps of probability of presence of bottlenose dolphins for low (0-0.15 ms-1), intermediate (0.15$0.5 \mathrm{~ms}-1)$ and high (>0.5 ms-1) current speeds, with associated bottlenose dolphin presence points recorded during follows in each corresponding tidal condition. Note that high current speeds $(>0.5 \mathrm{~ms}-1)$ did not occur in the entire surveyed area, compared to low or intermediate current speeds.

\section{$848 \times 1170 \mathrm{~mm}(72 \times 72 \mathrm{DPI})$}

